\title{
Prepartum concentrate supplementation of a diet based on medium- quality grass silage: Effects on performance, health, fertility, metabolic function, and immune function of low body condition score cows
}

\author{
M. W. Little,${ }^{*} \dagger^{1}$ N. E. O’Connell, $†$ M. D. Welsh, $\ddagger$ J. Barley, $\ddagger$ K. G. Meade, $\S$ and C. P. Ferris ${ }^{*}$ \\ ${ }^{*}$ Agri-Food and Biosciences Institute, Sustainable Agri-Food Sciences Division, Large Park, Hillsborough, BT26 6DR, United Kingdom \\ †Institute for Global Food Security, School of Biological Sciences, Queen's University Belfast, 18-30 Malone Road, Belfast, BT9 5BN, \\ United Kingdom \\ $\ddagger$ Agri-Food and Biosciences Institute, Veterinary Sciences Division, Stoney Road, Belfast BT4 3SD, United Kingdom \\ §Animal and Bioscience Research Department, Animal and Grassland Research and Innovation Centre, Teagasc, Grange, Co. Meath, Ireland
}

\begin{abstract}
When cows with a "higher" body condition score (BCS) are oversupplied with energy during the dry period, postpartum energy balance is normally reduced, which can have a detrimental effect on immune competence and increase the infectious disease risk. However, within grassland-based systems higher yielding cows frequently have a low BCS at drying off. The effects on performance, health, and metabolic and immune functions of providing additional energy to cows with low BCS during the dry period is less certain. To address this uncertainty, 53 multiparous Holstein-Friesian cows (mean BCS of $2.5 ; 1-5$ scale) were allocated to 1 of 2 treatments at dry-off: silage only or silage plus concentrates. Cows on the silage-only treatment were offered ad libitum access to medium-quality grass silage. Cows on the silage-plus-concentrate treatment were offered ad libitum access to a mixed ration comprising the same grass silage plus concentrates [in a 75:25 dry matter (DM) ratio], which provided a mean concentrate DM intake of $3.0 \mathrm{~kg} /$ cow per day. Postpartum, cows were offered a common mixed ration comprising grass silage and concentrates (in a 40:60 DM ratio) for a 70-d period. Offering concentrates during the dry period increased DM intake, tended to increase energy balance, and increased body weight (BW) and BCS gain prepartum. Offering concentrates during the dry period increased BW and BCS loss postpartum and tended to increase milk fat percentage and serum nonesterified fatty acid concentration, but it did not affect postpartum DM intake, energy balance, and milk yield. Although the percentage of phagocytosis-positive neutrophils did not differ, neutrophils from cows on the silage-plus-concentrate treatment had higher phagocyt-
\end{abstract}

Received February 22, 2016.

Accepted May 21, 2016.

${ }^{1}$ Corresponding author: mark.little@afbini.gov.uk ic fluorescence intensity at 1 and 2 wk postpartum and higher phagocytic index at 1 wk postpartum. Serum haptoglobin concentrations and IFN- $\gamma$ production by pokeweed mitogen stimulated whole blood culture were unaffected by treatment, although haptoglobin concentrations increased and IFN- $\gamma$ production decreased peripartum. Offering concentrates during the dry period increased the incidence of lameness postpartum, although other health and fertility parameters were unaffected. In conclusion, supplementing low BCS cows with concentrates during the dry period had no effect on performance and fertility and resulted in a higher neutrophil phagocytic index at $1 \mathrm{wk}$ postpartum and an increased incidence of lameness compared with offering cows a grass silage-only diet prepartum.

Key words: dairy cow, transition period, concentrate supplementation, immunity

\section{INTRODUCTION}

The transition period is defined as the last $3 \mathrm{wk}$ of gestation and the first 3 wk of lactation (Grummer, 1995; Drackley, 1999). During this time the cow must adapt to number of changes that occur in quick succession, including moving from a pregnant to a lactating state (with associated hormonal and metabolic changes and challenges), changes in social grouping and daily routine, and diet changes (which can often be dramatic). Of these transition period changes, the challenge of increasing metabolic demands are of particular importance (Grummer, 1995; Goff and Horst, 1997; Drackley, 1999). Prepartum, energy demands increase due to fetal growth and colostrogenesis (Bell, 1995), while DMI (and therefore energy supply) declines (Hernandez-Urdaneta et al., 1976; Johnson and Otterby, 1981). Postpartum, the rapid increase in energy requirements for milk production outpaces what can be supplied by DMI (Bell, 1995; Drackley, 1999). This imbalance between energy supply and demand means that negative energy bal- 
ance (EB) frequently occurs, contributing to the high incidence of metabolic disease at this time (Goff and Horst, 1997; Friggens et al., 2004).

The change in blood metabolites due to negative EB have been shown to impair immune function. For example, low blood glucose results in less energy being available for neutrophil phagocytosis (Newsholme et al., 1986; Roche et al., 2013), higher ketone levels impair neutrophil phagocytic and bactericidal capacity (Suriyasathaporn et al., 2000), and higher nonesterified fatty acids (NEFA) levels decrease neutrophil viability (Scalia et al., 2006). These findings are in keeping with comparisons between intact and mastectomized cows, which demonstrated that the metabolic stress associated with early lactation slowed the recovery of the normal peripartum decrease in neutrophil activity and adhesion molecule expression (Kimura et al., 1999). This periparturient immune suppression occurs at a time of increased challenge from bacteria, including those responsible for mastitis (Bradley and Green, 2004) and metritis (Sheldon et al., 2008), resulting in an increased risk of infectious diseases.

Therefore, failure to adapt to the physiological challenges arising during the transition period can increase the risk of both metabolic and infectious diseases (Goff and Horst, 1997; Ingvartsen, 2006). Any diseases that occur at this time can lead to reductions in DMI and milk production during the subsequent lactation (Roche et al., 2013) and can have detrimental effects on reproductive performance (Staples et al., 1990; Bobe et al., 2004; Roche et al., 2013). In recognition of the importance of the transition period, research has sought to develop nutritional and management strategies that aid the cow in adapting to the physiological challenges that occur at this time. Nutritional strategies designed to ensure a successful transition often focus on the dry period, with strategies designed to "regulate" energy intake (both restricting and increasing) often advocated. Strategies to increase energy intake during the dry period are designed to reduce the extent of prepartum negative EB and thus reduce the serum concentrations of the associated metabolites and their detrimental effects. Indeed, evidence exists that increasing energy intake (Dann et al., 1999; Vandehaar et al., 1999; Rabelo et al., 2005) and maximizing DMI (Grummer, 1995) in cows during the close-up period is beneficial to transition success and can result in improvements in immune function, such as enhanced immunoglobulin production (Stabel et al., 2003). However, other studies have shown that overconsumption of energy prepartum can have a deleterious effect on postpartum DMI, serum NEFA, and BHB concentrations (Dann et al., 2006; Douglas et al., 2006; Janovick and Drackley, 2010) and on hepatic adipose accumulation (Rukkwamsuk et al., 1998).
However, the response to energy intake during the dry period must be considered within the context of the cow's BCS. For example, it is generally accepted that dry cow nutritional management should prevent cows becoming overconditioned because cows with excessive body tissue reserves have poorer appetites pre- and postpartum, mobilize more lipid around calving (Ingvartsen et al., 2003; Friggens et al., 2004), and have a more severe periparturient immune depression, for example, depression in lymphocyte function (Lacetera et al., 2005). Indeed, studies that have observed benefits with restricted energy intakes during the dry period have involved cows with mean BCS 2.9 to 3.3 (1-5 scale) during the dry period (Dann et al., 2006; Douglas et al., 2006; Janovick and Drackley, 2010). In addition, diet and management systems clearly have an important effect on dry period BCS, with a recent review by Drackley and Cardoso (2014) highlighting that the problem of excessive prepartum BCS and subsequent excessive postpartum mobilization of lipid to particularly be an issue in herds where corn (maize) silage is the primary forage. In contrast, when higher yielding cows are managed within grassland-based systems, in which diets are based on grazed grass and grass silage, the problem is often one of "underconditioned" cows during the dry period. For example, in a study involving more than 1,200 dairy cows on 10 Northern Ireland dairy farms, $88 \%$ of the cows had a BCS or 2.5 or less at dry-off [R. A. Law (Agri-Food and Biosciences Institute, Hillsborough, Northern Ireland) and C. P. Ferris, unpublished data]. Thus, in these thinner cows the response to receiving additional energy during the dry period may be very different compared with that observed in higher BCS cows. This expectation is supported by the findings of a recent study that demonstrated the need to consider tailoring the dry cow diet to cow BCS (Roche et al., 2015). In this study, when measuring indictors of immune competence, optimally conditioned cows benefited from a short-term feed restriction during the dry period, but lower BCS cows benefited from a diet that met requirements.

Increasing energy intakes during the dry period is also often advocated as a strategy that may improve $\mathrm{BCS}$, although the extent of the associated changes is often small (Agenäs et al., 2003; Dann et al., 2006; Law et al., 2011). In addition, the decline in DMI that regularly precedes calving can be abated by increasing dry period energy intakes (Keady et al., 2001; McNamara et al., 2003b; Rabelo et al., 2003). In practice, one of the easiest ways to increase energy intakes during the dry period is to offer additional concentrates, and although this practice is common on many dairy farms, the benefits are often debated. Concentrate feeding during the dry period may also help prepare the rumen 
to better adapt to the higher quality postcalving diet. For example, evidence shows that offering concentrates may promote the development of rumen microflora more suited to higher concentrate early lactation diets (Andersen et al., 1999) and may also stimulate rumen papillae development, thus enhancing VFA absorption and in turn reducing the risk of subacute ruminal acidosis in early lactation (Dirksen et al., 1985). These effects on rumen function may contribute to the higher postcalving DMIs that have been reported in cows with higher concentrate intakes during the dry period (Grummer, 1995; McNamara et al., 2003b; Grummer et al., 2004).

Thus, the objectives of the present study were to examine the effects of offering a concentrate supplement (in addition to a medium-quality grass silage) throughout the dry period to cows with a lower BCS (mean 2.5 at drying off) on performance, health, fertility, and blood metabolites. We hypothesize that offering additional concentrates to thin cows during the dry period has a beneficial effect on immunity during the transition period and on subsequent performance.

\section{MATERIALS AND METHODS}

\section{Animals and Housing}

This study involved 53 multiparous (mean parity, 3.3; SD, 1.19) Holstein-Friesian dairy cows. Cows had a mean $\mathrm{PTA}_{2015}$ for milk yield and fat plus protein yield of $71 \mathrm{~kg}(\mathrm{SD}, 148.3)$ and $15.0 \mathrm{~kg}(\mathrm{SD}, 9.66)$, respectively, and a mean profitable lifetime index $\left(\mathrm{PLI}_{2014}\right)$ of $£ 148$ (SD, 109.9). These cows were within the top $1 \%$ of UK genetics in terms of profitable lifetime index. All procedures described in this article were conducted under and in compliance with the United Kingdom Animals (Scientific Procedures) Act (1986; http://www. legislation.gov.uk/ukpga/1986/14/contents).

Throughout the experiment (except at calving) cows were housed in a freestall cubicle house with concrete flooring, which was scraped every $3 \mathrm{~h}$ by an automated system. The cubicle to cow ratio was 1:1 or higher at all times, thus meeting the recommendations of the Farm Animal Welfare Council (1997). Cubicles were fitted with rubber mats and were bedded 3 times each week with sawdust.

\section{Experimental Design, Diets, and Feeding}

Cows were dried off over an 11-wk period (mean dryoff date, December 22; SD, 3.38 d), with cows normally dried off at either 8 wk (if BCS was $\geq 2.5$ ) or $10 \mathrm{wk}$ (if BCS was $<2.5)$ before their expected calving date. Several cows $(\mathrm{n}=9)$ had an "extended" dry period due to being dried off when their milk yields fell below $5.0 \mathrm{~kg} /$ cow per day, with these cows offered a silage-only diet from drying-off until $8 \mathrm{wk}$ before their expected calving date. Cows were assigned to 1 of 2 treatment groups, silage only or silage plus concentrate, at dry-off, or in the case of the cows with an extended dry period, at $8 \mathrm{wk}$ before their expected calving date [the actual number of days from treatment implementation to calving was $65 \mathrm{~d}$ (SD, 9.6)]. These 2 experimental treatments were implemented from this time until the time of calving, including the time spent in the maternity pen. Cows on each treatment were balanced for expected calving date, parity, previous lactation 305-d milk yield, preallocation BW and BCS, PTA for fat plus protein $(\mathrm{kg})$, number of services during the previous lactation, and expected calving interval.

With the silage-only treatment, cows $(\mathrm{n}=26)$ were offered ad libitum access to a diet comprising mediumquality grass silage throughout the dry period. With the silage-plus-concentrate treatment, cows $(\mathrm{n}=27)$ were given ad libitum access to a mixed diet comprising the same medium-quality grass silage plus concentrates (mixed in a $75: 25$ DM ratio), which was designed to provide an average concentrate intake of approximately $3.0 \mathrm{~kg} /$ cow per day. The experimental diets were designed to be representative of typical UK on-farm management strategies and to provide approximately 100 and $130 \%$ of the cow's ME requirement during the dry period (ME intake of 106 and $138 \mathrm{MJ} / \mathrm{d}$ with the silage-only and silage-plus-concentrate treatments, respectively), based on the equations contained within Feed into Milk (Agnew et al., 2004), the current UK rationing system for dairy cows. The ingredient composition of the prepartum concentrate offered $(\mathrm{g} / \mathrm{kg}$ fresh basis) was as follows: maize, 238; wheat feed, 127; corn gluten, 150; soya hulls, 300; soybean meal, 80; rapeseed meal, 70; Molaferm (United Molasses, Belfast, UK) 35.

The grass silage offered with both treatments was produced from a secondary regrowth herbage harvested from predominantly perennial ryegrass-based swards (harvest dates, August 13-28) and ensiled following a 24- to 48-h period of field wilting. Throughout the dry period, cows on both treatments were supplemented with a dry cow mineral/vitamin mix (Trouw Nutrition, Cheshire, UK), which was included in the mix to achieve a target intake of $100 \mathrm{~g} /$ cow per day. In addition, during the 3 -wk period before the expected calving date, cows on both treatments were supplemented with Calcined Magnesite (Trouw Nutrition), which was included in the mix to achieve a target intake of $50 \mathrm{~g} / \mathrm{cow}$ per day. Rations were prepared daily using a complete diet mixer wagon (Redrock Varicut, Redrock, Northern Ireland). The experimental diets for each treatment were transferred directly from the mixer wagon to feed-boxes 
mounted on weigh cells, access to which was controlled by a Calan Gate feeding system (American Calan Inc., Northwood, NH) linked to an electronic identification system, thus enabling individual cow intakes to be recorded daily. Cows within each treatment group were able to feed from several feed boxes, and a feed box to cow ratio of $\geq 1: 3$ was maintained at all times. Both diets were offered ad libitum at $107 \%$ of the previous day's intake. Uneaten ration was removed daily at approximately $0800 \mathrm{~h}$, and the fresh ration was offered between 0900 and $1000 \mathrm{~h}$.

Cows were moved to a maternity pen bedded with straw 24 to $48 \mathrm{~h}$ before their expected calving, based on physical observations. At parturition, calving difficulty was recorded as follows: $1=$ unobserved; $2=$ assisted without calving aid; $3=$ assisted with calving aid; $4=$ veterinary assisted; and $5=$ calf delivered by cesarean section. Calves were weighed immediately after birth using a weigh scale. Post calving (normally within 12-24 $\mathrm{h}$ ), cows were moved from the maternity pen to the cow house described earlier, with all cows offered ad libitum access to a common ration, which comprised grass silage and concentrates (mixed in a 40:60 DM ratio) via the Calan gate feeding system described earlier. Cows were also offered an additional $0.5 \mathrm{~kg}$ of concentrate at each milking via in-parlor feeders. The ingredient composition of the postpartum concentrate offered $(\mathrm{g} / \mathrm{kg}$ fresh basis) was as follows: maize, 171; soybean meal, 132; wheat, 128; rapeseed meal, 125; corn gluten, 124; soyhulls, 101; palm kernel, 99; wheat feed, 45; Molaferm 40; lime flour, 9.5; palm oil, 9.5; salt, 8.0; calcined magnesite (Trouw Nutrition), 4.0; mineral/vitamin mix (Superdairy, Trouw Nutrition), 4.0; and Actisaf (Lesaffre, Shannon, Ireland), 0.5. The grass silage offered was produced from a primary growth herbage that was harvested from perennial ryegrass-dominated swards (harvest dates, June 26-28) and ensiled following a 24to 48 -h period of field wilting. Cows remained on this diet until day 70 of lactation (end of study).

\section{Feed Analysis}

Samples of grass silage were taken daily, dried at $85^{\circ} \mathrm{C}$ for $18 \mathrm{~h}$ to determine oven DM content (prepartum $\mathrm{n}=$ 148 , postpartum $\mathrm{n}=170$ ), and milled through a sieve with 0.8-mm apertures. Subsamples of the dried milled silages were collected twice weekly and composited every $14 \mathrm{~d}$ (prepartum $\mathrm{n}=10$, postpartum $\mathrm{n}=12$ ), with the composited sample analyzed for NDF, ADF, and ash. In addition, a sample of the fresh silage offered was taken weekly (prepartum $\mathrm{n}=20$, postpartum $\mathrm{n}=$ 24) and analyzed for ME concentration; a second fresh sample was analyzed for $\mathrm{pH}$, gross energy, CP (nitrogen $\times 6.25)$, ammonia-nitrogen, and fermentation acid (lactic acid and acetic acid) concentrations. Volatility coefficients were used to convert the oven DM contents of the grass silages offered to a volatile-corrected dry matter basis. A sample of the concentrates offered was taken once weekly (prepartum $\mathrm{n}=20$, postpartum $\mathrm{n}=$ 24 ), dried at $100^{\circ} \mathrm{C}$ for $24 \mathrm{~h}$ before milling through a 0.8-mm sieve, and composited every $14 \mathrm{~d}$. A subsample was analyzed for NDF, ADF, ash, gross energy, and CP (nitrogen $\times 6.25)$ concentrations.

Concentrations of NDF and ADF were determined using a Fibertec analyzer (Fibertec FT122, Foss, Hillerød, Denmark) based on the method by Cushnahan and Gordon (1995), and ash concentrations were determined following combustion in a muffle furnace at $550^{\circ} \mathrm{C}$ for approximately $10 \mathrm{~h}$. Metabolizable energy concentration was determined by near infrared reflectance spectroscopy according to Park et al. (1998), and gross energy concentration was measured by using a bomb calorimeter (Parr 6300 Bomb Calorimeter, Parr Instrument Co., Moline, IL). The nitrogen concentration was determined using the Kjeldahl method (Tecator Kjeltec Auto 2400/2460 Analyzer/Sampler System, Foss) and ammonia nitrogen as described by Steen (1989). Lactic acid and acetic acid concentrations were determined using single column GLC equipped with a flame-ionization detector (Varian Star 3400 CX GC, Varian Inc., Palo Alto, CA). Volatility coefficients were applied according to Porter and Murray (2001).

\section{Measurements of Cow Performance}

Ration intakes for each individual cow were recorded daily using the intake recording system described earlier. Cows were milked twice daily between 0530 and $0700 \mathrm{~h}$ and 1530 and $1700 \mathrm{~h}$ through a 50-point rotary milking parlor. Individual cow milk yields were automatically recorded at each milking, and a mean daily milk yield was calculated for each cow on a weekly basis. Milk yields were not recorded during the first $5 \mathrm{~d}$ after calving, and these values were subsequently estimated by plotting a linear response through milk yields during d 6 to 15 after calving and interpolating back for d 1 to 5 . Milk samples were obtained once weekly from 2 consecutive milkings (a.m. and p.m.), a preservative tablet was added (Broad Spectrum Microtabs II, D\&F Control Systems, Norwood, MA), and samples were stored at $4^{\circ} \mathrm{C}$ until analyzed. These samples were analyzed weekly for fat, protein, and lactose content by Fourier transform infrared spectroscopy using an infrared milk analyzer (Milkoscan, model FT 120, Foss UK Ltd., Warrington, UK), and a weighted milk composition was subsequently calculated for each sampling occasion. In addition, a single milk sample was collected from each cow on 2 occasions each week 
(p.m.) until $60 \mathrm{~d}$ postpartum for progesterone analysis. Samples were preserved and stored as above (for a maximum of $3 \mathrm{wk}$ ), with progesterone concentrations subsequently determined using a competitive ELISA kit (Ridgeway Science Ltd., Gloucestershire, UK), with the assay based on the method of Sauer et al. (1986). On 1 occasion each month, samples from 2 consecutive milkings, bulked in proportion to yield, were collected and SCC measured (model CA3A4, Delta Instruments, Drachten, the Netherlands).

All individual cow health events and treatments were recorded. Cow BW were recorded weekly during the prepartum period and twice daily (using an automatic weigh scale) from calving until the end of the study. Cow BCS were recorded weekly during the prepartum and postpartum periods, using a 1 to 5 scale (Edmonson et al., 1989) with quarter-point increments. All estrus events were recorded for the duration of the study. After the 42-d voluntary waiting period, cows were inseminated $12 \mathrm{~h}$ after visual observation of estrus. With the exception of cows treated for uterine infections and follicular cysts, no other reproductive treatments were given until after d 80 of lactation. Pregnancy was diagnosed via an ultrasound scan conducted by a veterinary surgeon at d 60 postinsemination.

The mean daily ME requirements and balances for each cow were calculated using the equations of Agnew et al. (2004), where daily mean EB (MJ/cow per day) was determined as

$$
\text { Mean EB }=\left[\begin{array}{l}
\left(\mathrm{ME}_{\text {main }+ \text { milk }} \times \mathrm{BW}^{0.75}\right) \\
+\left[\frac{(0.0013 \times \mathrm{BW})}{\mathrm{K}_{\mathrm{m}}}\right]+\mathrm{ME}_{\mathrm{c}}-10
\end{array}\right]-\mathrm{ME}_{\mathrm{i}} \text {, }
$$

where $\mathrm{ME}_{\text {main+milk }}$ is the $\mathrm{ME}$ required for maintenance and milk production (MJ/kg of metabolic weight), $\mathrm{BW}^{0.75}$ is metabolic BW, $\mathrm{K}_{\mathrm{m}}$ is the efficiency of utilization of ME for activity (calculated as $0.35 \times \mathrm{ME} /$ gross energy +0.503$), \mathrm{ME}_{\mathrm{c}}$ is the $\mathrm{ME}$ required for pregnancy, and $\mathrm{ME}_{\mathrm{i}}$ is the $\mathrm{ME}$ intake $(\mathrm{MJ} /$ cow per $\mathrm{d}$ ). Data for mean daily milk yield, milk fat, protein and lactose concentrations, and mean BW were used in the calculation of the $\mathrm{EB}$ variables.

\section{Vaginal Mucus Score Evaluation}

A clinical examination of vagina mucus was conducted during wk 1 (1-7 d), 2 (8-14 d), 3 (15-21 d), 4 (22-28 d), and $8(50-56 \mathrm{~d})$ postpartum, according to Williams et al. (2005). The cow's vulva was thoroughly cleaned using a disinfected paper towel and then dried. A clean lubricated gloved hand was then inserted through the vulva into the vaginal area. In each cow, the lateral, dorsal, and ventral walls of the vagina and the external cervical os were palpated, and the mucus contents of the vagina withdrawn manually for examination. The vaginal mucus was assessed and scored by a single operator throughout the course of the study for color, proportion, and volume of pus, and a character score assigned as follows: $0=$ clear or translucent mucus; $1=$ mucus containing flecks of white or off-white pus; $2=$ $<50 \mathrm{~mL}$ of exudate containing $\leq 50 \%$ white or off-white mucopurulent material; and $3=>50 \mathrm{~mL}$ of exudate containing purulent material, usually white or yellow, but occasionally sanguineous. The vaginal mucus was also assessed for odor, and given a score 0 for normal odor or a score of 1 if a fetid odor was detected. If a cow had a mucus score of 3 (or an elevated body temperature alongside a mucus score of 2) and an odor assessment of 1 , intrauterine antibiotics were administered (Metricure, Intervet/Schering-Plough Animal Health, Milton Keynes, UK).

\section{Blood Measurements}

Blood Biochemistry and Haptoglobin Analysis. Blood samples were obtained from the coccygeal vein or artery of each cow (0830-1030 h, before fresh food was offered) $5 \mathrm{wk}$ (29-35 d), $3 \mathrm{wk}(15-21 \mathrm{~d})$, and $1 \mathrm{wk}$ (1-7 d) before the predicted calving date, and 1, 2, 3, 4 , and 8 wk postpartum. Samples were collected into evacuated tubes (BD, Oxford, UK) that were either coated with a clot activator or fluoride oxalate. An additional sample was taken into a tube coated with a clot activator $7 \mathrm{wk}(43-49 \mathrm{~d})$ before the predicted calving date. The blood samples were centrifuged $(1,800 \times g$ at $17^{\circ} \mathrm{C}$ for $30 \mathrm{~min}$ ) to obtain serum (tubes with a clot activator) or plasma (fluoride oxalate tubes), which was separated and stored at $-20^{\circ} \mathrm{C}$ until analyzed. Plasma was analyzed for glucose concentrations, and serum was analyzed for albumin, BHB, glutamate dehydrogenase (GLDH), globulin, haptoglobin (Hp), NEFA, total protein, and urea concentrations. Serum biochemistry analysis was carried out on a dry chemistry analyzer system (Sapphire 800, Glenbio, UK), using Olympus kits (Olympus Life Science Research Europa, Munich, Germany). Serum Hp was measured using a Tridelta PHASE Haptoglobin Assay kit (Tridelta, Maynooth, County Kildare, Ireland) using the analyzer previously described.

Blood Hematology. Additional blood samples were collected in a lithium heparin tube 5,3 , and 1 wk before the predicted calving date and $1,2,3,4$, and 8 wk postpartum using the methodology already described. The whole blood sample was mixed thoroughly and the total leukocyte count was obtained using an automated 
hematology analyzer (Sysmex F-820, Sysmex Europe GmbH, Hamburg, Germany) within 6 h of collection. A differential cell count (lymphocyte, neutrophil, monocyte, and eosinophil) was also obtained by a manual count. Thin blood smears were prepared on grease-free glass slides (Leica Biosystems, Newcastle, UK), airdried, and stained using the Giemsa stain technique. One hundred cells were counted under a microscope (Leica Biosystems) at $\times 40$ magnification, and the cell type was morphologically identified.

Neutrophil Phagocytic Measurements. Additional blood samples were collected in lithium heparin tubes at $3 \mathrm{wk}$ before the predicted calving date, and at 1 and 2 wk postpartum for the measurement of the in vitro phagocytic capacity of neutrophils. The test and control samples were analyzed in duplicate within $3 \mathrm{~h}$ of collection, using the Phagotest kit (Orpegen Pharma GmbH, Heidelberg, Germany). Fifty microliters of heparinized whole blood was placed on ice for $10 \mathrm{~min}$, to which $20 \mu \mathrm{L}$ of stabilized and opsonized fluorescein isothiocyanate-labeled Escherichia coli was added. The test samples were incubated in a water bath at $38.5^{\circ} \mathrm{C}$ for $10 \mathrm{~min}$, and the control samples remained on ice for $10 \mathrm{~min}$. At the end of incubation, phagocytosis was halted by placing all samples onto ice. One hundred microliters of quenching solution was added to samples to eliminate the fluorescence of nonphagocytosed $E$. coli bacteria. Cells were washed using $3 \mathrm{~mL}$ of wash solution and centrifuged $\left(250 \mathrm{~g}\right.$ for $5 \mathrm{~min}$ at $\left.4^{\circ} \mathrm{C}\right)$, and supernatants were aspirated twice. Cells were then resuspended in $2 \mathrm{~mL}$ of lysing solution for $20 \mathrm{~min}$ at room temperature. After centrifugation and aspiration of supernatants to recover cells, these cells underwent another wash step with $3 \mathrm{~mL}$ of wash solution and centrifugation. The supernatants were resuspended in 100 $\mu \mathrm{L}$ of DNA-staining solution and incubated on ice for $10 \mathrm{~min}$ in the dark before analysis by flow cytometry.

Neutrophil Oxidative Burst Measurements. The blood samples collected for neutrophil phagocytic activity were also used to evaluate the in vitro oxidative burst activity of neutrophils. The test and control samples were analyzed in duplicate within $6 \mathrm{~h}$ of collection, using the Phagoburst kit (Orpegen Pharma $\mathrm{GmbH})$. Fifty microliters of heparinized whole blood was placed on ice for $10 \mathrm{~min}$, and then $20 \mu \mathrm{L}$ of opsonized E. coli was added to each test sample and 20 $\mu \mathrm{L}$ of wash solution was added to each control sample before incubation in a water bath at $38.5^{\circ} \mathrm{C}$. Twenty microliters of dihydrorhodamine 123 substrate was then added, and the tubes were mixed thoroughly before incubating for a further $10 \mathrm{~min}$ in a water bath at $38.5^{\circ} \mathrm{C}$. Two milliliters of lysing solution was added to samples and incubated for $20 \mathrm{~min}$ at room temperature to stop the reaction and fix the cells simultaneously. After cen- trifugation and aspiration of supernatants to recover cells, these samples underwent a wash step with $3 \mathrm{~mL}$ of wash solution and centrifugation. The supernatants were resuspended in $100 \mu \mathrm{L}$ of DNA-staining solution and incubated on ice for $10 \mathrm{~min}$ in the dark before analysis by flow cytometry.

Flow Cytometric Analysis. Whole blood flow cytometric analysis was performed on an Attune flow cytometer (Life Technologies, Thermo Fisher Scientific Inc., Waltham, MA), equipped with a violet/blue 405 $\mathrm{nm}$ and $488 \mathrm{~nm}$ laser and standard filter configuration (525 nm bandpass, $630 \mathrm{~nm}$ longpass). Data were analyzed using Attune Cytometric software (Life Technologies, Thermo Fisher Scientific Inc.). During data acquisition of phagocytic and oxidative burst assays, a live gate was set in green $530 \mathrm{~nm}$ fluorescence histogram (BL-1 channel) for those events having at least the same DNA content as diploid cells to exclude cell debris and bacterial aggregates. For all samples, 10,000 events were acquired. A gate identifying the neutrophil population was set using the forward and side scatter properties of these cells and corresponding green fluorescence histogram was analyzed. The control sample was used to set a threshold for fluorescence so that only 1 to $3 \%$ of the acquired events were positive. The number of events above this threshold was counted as the percentage of neutrophils actively carrying out phagocytosis or oxidative burst. The mean fluorescence intensity correlated to the number of bacteria phagocytosed by each cell or mean oxidative burst activity by a single cell. The phagocytic or oxidative burst index was the percentage of active neutrophils multiplied by the fluorescence intensity.

Interferon $\gamma$ Production. An additional blood sample was collected in a lithium heparin tube during wk 5,3 , and 1 before the predicted calving date and wk $1,2,3,4$, and 8 postpartum for the measurement of IFN- $\gamma$ production by stimulated peripheral blood mononuclear cells. Whole blood samples $(250 \mu \mathrm{L})$ were cultured (commencing within $3 \mathrm{~h}$ of collection) in triplicate using flat bottom 96-well tissue culture plates, with $30 \mu \mathrm{L}$ of PBS and $30 \mu \mathrm{L}$ of $5 \mu \mathrm{g} / \mathrm{mL}$ of pokeweed mitogen (PWM; lectin from Phytolacca americana) in PBS. Plates were incubated for $24 \mathrm{~h}$ at $37^{\circ} \mathrm{C}$ and $5 \%$ $\mathrm{CO}_{2}$, and then centrifuged $\left(2000 \mathrm{~g}\right.$ at $18^{\circ} \mathrm{C}$ for $\left.15 \mathrm{~min}\right)$ to obtain supernatants, which were stored at $-20^{\circ} \mathrm{C}$ until analyzed. The concentration of IFN- $\gamma$ was then determined using an ELISA kit (Biopanda Reagents, Belfast, UK) with samples being tested in triplicate. The sample incubated with PBS was used as a negative control to look at the inherent IFN- $\gamma$ level, and the sample incubated with PWM was used as a positive stimulant of peripheral blood mononuclear cells to produce IFN- $\gamma$. 


\section{Statistical Analysis}

Two cows were removed from the experiment (one because of severe $E$. coli mastitis following calving and one because of injury), and their data were excluded from the statistical analysis, leaving 51 cows in the study (26 on the silage-plus-concentrate treatment and 25 on the silage-only treatment). Data were analyzed using GenStat Version 16.2 (VSN International, Oxford, UK). Data describing DMI, milk yield, milk constituents, milk constituent yield, BW, $\mathrm{BCS}$, mean daily $\mathrm{EB}$, calf birth weight, somatic cell score ( $\log _{\mathrm{e}}$ transformed somatic cell count), days to onset of corpus luteal activity, maximum progesterone concentration of the first corpus luteum, and flow cytometric analysis of neutrophil phagocytosis and oxidative burst were analyzed using ANOVA. Where significant in the model, appropriate pre-experimental variables were included as covariates when analyzing corresponding dependent variables. For example, milk yield was analyzed with the addition of previous lactation 305-d milk yield in the model. Similarly, milk fat composition, milk protein composition, milk fat plus protein yields, BW, and BCS were analyzed with the addition of previous lactation fat composition, previous lactation protein composition, previous lactation fat plus protein yield, pre-experimental BW, and preexperimental BCS, respectively, in the model. Weekly data for mean daily total DMI, BW, BCS, EB, blood hematology, serum biochemistry, Hp, and IFN- $\gamma$ were analyzed using repeated measures REML analysis. The mixed model used included the following terms as fixed effects: treatment + week + treatment $\times$ week. Cow $x$ week was included in the random model, to which a power model (city block metric) covariance structure was applied. Similarly, BW and BCS were analyzed as before, with the addition of pre-experimental BW and BCS, respectively, in the mixed model. Data describing calving difficulty, health treatments, mucus score at wk 8 , corpus luteal activity at $<42 \mathrm{~d}$, fertility outcomes, and fertility treatments were analyzed using generalized linear model regression analysis with the logit link function. The model included treatment as a term and significance was identified using chi-squared testing. Data describing vaginal mucus scores at wk 1, 2, 3, and 4 were analyzed using ordinal logical regression with the logit link function and significance was identified using chi-squared testing. Vaginal mucous scores data were translated into one integer $(0=0,0 ; 1=1,0 ; 2$ $=2,0 ; 3=3,0 ; 4=2,1 ; 5=3,1)$ and were grouped into 3 categories for analysis $(0,1, \geq 2)$.

\section{RESULTS}

The grass silage offered prepartum was medium quality (oven DM, CP, and ME content of $233 \mathrm{~g} / \mathrm{kg}, 148$ $\mathrm{g} / \mathrm{kg}$ of $\mathrm{DM}$, and $10.5 \mathrm{MJ} / \mathrm{kg}$ of DM, respectively) and well fermented (pH, ammonia $\mathrm{N}$, and lactic acid of 3.89, $106 \mathrm{~g} / \mathrm{kg}$ of total $\mathrm{N}$, and $105 \mathrm{~g} / \mathrm{kg}$ of DM, respectively), and the respective values for the grass silage offered postpartum were $295 \mathrm{~g} / \mathrm{kg}, 107 \mathrm{~g} / \mathrm{kg}$ of DM, $11.0 \mathrm{MJ} /$ $\mathrm{kg}$ of DM, 3.92, $77 \mathrm{~g} / \mathrm{kg}$ of total $\mathrm{N}$, and $91 \mathrm{~g} / \mathrm{kg}$ of DM (Table 1).

Cows on the silage-plus-concentrate treatment consumed $3.0 \mathrm{~kg}$ of DM concentrate/d from the mixed diet offered prepartum. Although prepartum silage DMI was unaffected $(P>0.1)$ by treatment, total DMI was higher $(P<0.001)$ with the silage-plus-concentrate treatment (Table 2). Treatment had no effect $(P>$ 0.1 ) on concentrate, silage, or total DMI postpartum,

Table 1. Chemical composition (SD in parentheses) of grass silage and concentrates offered during the prepartum and postpartum period

\begin{tabular}{|c|c|c|c|c|}
\hline \multirow[b]{2}{*}{ Item } & \multicolumn{2}{|c|}{ Prepartum } & \multicolumn{2}{|c|}{ Postpartum } \\
\hline & Grass silage & Concentrate & Grass silage & Concentrate \\
\hline Oven DM (g/kg) & $233(22.5)$ & $883(5.6)$ & $295(41.7)$ & $889(9.7)$ \\
\hline $\operatorname{VCODM}^{1}(\mathrm{~g} / \mathrm{kg})$ & $242(19.6)$ & - & $304(40.7)$ & - \\
\hline $\mathrm{pH}$ & $3.89(0.278)$ & - & $3.92(0.247)$ & - \\
\hline Ammonia-N (g/kg of total $\mathrm{N}$ ) & $106(28.0)$ & - & $77(11.5)$ & - \\
\hline \multicolumn{5}{|c|}{ Composition of DM ( $\mathrm{g} / \mathrm{kg}$ of VCODM) } \\
\hline $\mathrm{CP}$ & $148(12.4)$ & $187(4.6)$ & $142(8.7)$ & $203(5.2)$ \\
\hline Lactic acid & $105.0(10.9)$ & - & $91.2(13.9)$ & - \\
\hline Acetic acid & $23.8(3.4)$ & - & $23.5(2.4)$ & - \\
\hline $\mathrm{ADF}$ & $329(17.7)$ & $233(8.3)$ & $334(27.0)$ & $209(7.6)$ \\
\hline NDF & $556(29.2)$ & $368(23.3)$ & $560(44.8)$ & $394(63.4)$ \\
\hline Ash & $107(12.7)$ & $53(13.8)$ & $90(11.3)$ & $60(14.2)$ \\
\hline Gross energy (MJ/kg of DM) & $19.3(0.41)$ & $18.3(0.31)$ & $19.4(0.68)$ & $18.4(0.28)$ \\
\hline $\mathrm{ME}(\mathrm{MJ} / \mathrm{kg}$ of DM) & $10.5(0.50)^{2}$ & $12.6^{3}$ & $11.0(0.48)^{2}$ & $12.5^{3}$ \\
\hline
\end{tabular}

${ }^{1}$ VCODM $=$ volatile-corrected oven dry matter.

${ }^{2}$ Predicted using near infrared reflectance spectroscopy.

${ }^{3}$ Calculated from standard values. 
mean daily milk yield, milk protein concentration, milk lactose concentration, milk fat yield, milk protein yield, milk fat plus protein yield, and somatic cell score. However, milk from cows on the silage-plus-concentrate treatment tended $(P=0.072)$ to have a higher milk fat concentration than milk from cows on the silage-only treatment (Table 2).

During the prepartum period, cows on the silageplus-concentrate treatment had a higher mean BW $(P$ $<0.001)$, greater $\mathrm{BW}$ gain $(P<0.001)$, higher mean BCS $(P=0.003)$, greater BCS gain $(P=0.025)$, and greater mean daily $\mathrm{EB}(P<0.001)$ than cows on the silage-only treatment (Table 3 ). During the postpartum period cows on the silage-plus-concentrate treatment had a higher mean $\mathrm{BW}(P<0.001)$, greater $\mathrm{BW}$ loss to nadir $(P<0.001)$, greater number of days to nadir BW $(P=0.043)$, greater BW loss to d $70(P<0.001)$, higher mean BCS $(P=0.012)$, and a greater BCS loss to $\mathrm{d} 70(P=0.016)$ than cows on the silage-only treatment. However, treatment had no effect $(P>0.1)$ on mean daily EB postpartum (Table 3).

When weekly data were examined using a repeated measures analysis, cows on the silage-plus-concentrate treatment had a greater total DMI prepartum $(P<$ $0.001)$ than those on the silage-only treatment, although total DMI postpartum was unaffected by treatment $(P$ $>0.1$ ). Total DMI changed over the prepartum and postpartum periods (time: $P<0.001$ ), and a treatment $\times$ time interaction was apparent for total DMI during both the prepartum and postpartum periods $(P$
$=0.032, P=0.027$, respectively) (Figure 1a). Cows on the silage-plus-concentrate treatment had a greater BW both prepartum and postpartum $(P<0.001)$. Bodyweight increased during the prepartum period and decreased during the postpartum period (time: $P<$ 0.001 ), and a treatment $\times$ time interaction was seen during both the prepartum and postpartum periods $(P<0.001)$ (Figure 1b). Cows on the silage-plus-concentrate treatment had a greater BCS both prepartum and postpartum $(P=0.003, P=0.010$, respectively $)$ than those on the silage-only treatment. Body condition score increased during the prepartum period and decreased during the postpartum period (time: $P<$ $0.001)$, although no treatment $\times$ time interaction $(P>$ 0.1 ) occurred either prepartum or postpartum (Figure 1c). Cows on the silage-plus-concentrate treatment had a higher prepartum $\mathrm{EB}(P<0.001)$ and tended to have a lower postpartum EB $(P=0.099)$ than those on the silage-only treatment. Energy balance decreased during the prepartum period and increased during the postpartum period ( $P<0.001, P=0.002$, respectively), with a significant treatment $\times$ time interaction postpartum $(P=0.034)$, but not prepartum $(P>0.1)$ (Figure 1d).

Treatment had no effect $(P>0.1)$ on red cell count, hemoglobin content, packed cell volume, white cell count, lymphocyte percentage, or neutrophil percentage prepartum (Table 4$)$. Hemoglobin content $(P=$ $0.014)$, packed cell volume $(P=0.027)$, white cell count $(P=0.029)$, and neutrophil percentage $(P=0.005)$ increased, but lymphocyte percentage decreased $(P=$

Table 2. Effects of concentrate supplementation during the dry period on prepartum and postpartum DMI, milk yield, milk constituents, milk constituent yields, SCC, and SCS during the first $70 \mathrm{~d}$ of lactation

\begin{tabular}{|c|c|c|c|c|}
\hline \multirow[b]{2}{*}{ Item } & \multicolumn{2}{|c|}{ Prepartum treatment } & \multirow[b]{2}{*}{$\mathrm{SED}^{1}$} & \multirow[b]{2}{*}{$P$-value } \\
\hline & $\begin{array}{l}\text { Silage } \\
\text { only }\end{array}$ & $\begin{array}{l}\text { Silage plus } \\
\text { concentrates }\end{array}$ & & \\
\hline \multicolumn{5}{|c|}{ Prepartum DMI (kg/cow per day) } \\
\hline Concentrate & 0.0 & 3.0 & & \\
\hline Silage & 10.1 & 10.1 & 0.36 & 0.884 \\
\hline Total & 10.1 & 13.1 & 0.36 & $<0.001$ \\
\hline \multicolumn{5}{|c|}{ Postpartum DMI (kg/cow per day) } \\
\hline Concentrate & 13.9 & 13.5 & 0.41 & 0.337 \\
\hline Silage & 8.1 & 7.7 & 0.29 & 0.169 \\
\hline Total & 22.0 & 21.2 & 0.68 & 0.210 \\
\hline Milk yield (kg/cow per day) & 39.0 & 39.4 & 1.48 & 0.830 \\
\hline \multicolumn{5}{|l|}{ Milk constituents $(\mathrm{g} / \mathrm{kg})$} \\
\hline Fat & 44.3 & 46.5 & 1.2 & 0.072 \\
\hline Protein & 32.1 & 32.5 & 0.53 & 0.475 \\
\hline Lactose & 46.8 & 46.6 & 0.22 & 0.584 \\
\hline \multicolumn{5}{|c|}{ Milk constituent yield (kg/cow per day) } \\
\hline Fat & 1.72 & 1.84 & 0.096 & 0.206 \\
\hline Protein & 1.24 & 1.28 & 0.050 & 0.466 \\
\hline Fat + protein & 2.97 & 3.11 & 0.120 & 0.239 \\
\hline $\mathrm{SCC}(\times 1,000 / \mathrm{mL})$ & 194 & 209 & & \\
\hline $\mathrm{SCS}^{2}$ & 11.09 & 11.58 & 0.34 & 0.150 \\
\hline
\end{tabular}

${ }^{1}$ Standard error of the difference.

${ }^{2}$ Natural logarithm $\left(\log _{\mathrm{e}}\right)$ of SCC. 
0.017) during the prepartum period (Table 4). A treatment $\times$ time interaction was observed with hemoglobin $(P=0.024)$ and packed cell volume $(P=0.020)$ prepartum, but the treatment had no effect $(P>0.1)$ on red cell count, white cell count, lymphocyte percentage, and neutrophil percentage postpartum. However, cows on the silage-plus-concentrate treatment had a higher postpartum hemoglobin $(P=0.002)$ and packed cell volume $(P=0.014)$ than cows on the silage-only treatment. Red cell count $(P<0.001)$, hemoglobin content $(P<0.001)$, packed cell volume $(P<0.001)$, and lymphocyte percentage $(P=0.002)$ decreased, but white cell count $(P<0.001)$ and neutrophil percentage $(P$ $=0.005)$ increased during the postpartum period. No postpartum treatment $\times$ time interaction $(P>0.1)$ was observed for any of the parameters presented (Table 4). Treatment had no effect $(P>0.1)$ on concentrations of serum globulin (36.7 and $39.5 \mathrm{~g} / \mathrm{L}$ for the silage-only and silage-plus-concentrate treatments, respectively, $\mathrm{SED}=1.55, P=0.124$ ), GLDH (Figure 2b), or NEFA (Figure 2d) prepartum. However, cows on the silageplus-concentrate treatment tended to have a higher serum albumin concentration $(26.5$ and $28.1 \mathrm{~g} / \mathrm{L}$ for the silage-only and silage-plus-concentrate treatment, respectively, SED $=0.73, P=0.053)$ and had higher concentrations for serum BHB $(P<0.001)$ (Figure 2a), glucose $(P=0.002)$ (Figure 2c), total protein (63.2 and $67.5 \mathrm{~g} / \mathrm{L}$ for the silage-only and silage-plus-concentrate treatments, respectively, $\mathrm{SED}=1.85, P=0.038)$, and urea (3.62 and $4.09 \mathrm{mM}$ for the silage-only and silageplus-concentrate treatment, respectively, $\mathrm{SED}=0.218$, $P=0.035)$ than cows on the silage-only treatment prepartum. During the prepartum period, concentrations of serum BHB $(P<0.001)$ (Figure 2a), GLDH $(P$ $=0.001)$ (Figure $2 \mathrm{~b}$ ), and NEFA $(P<0.001)$ (Figure 2d) increased, serum albumin concentration (SED = $0.57, P=0.078)$ tended to decrease, and concentrations of serum globulin $(\mathrm{SED}=1.02, P<0.001)$ and total protein $(\mathrm{SED}=1.42, P<0.001)$ decreased. With the exception of serum albumin $(\mathrm{SED}=0.93, P=0.064)$, no evidence $(P>0.1)$ of a treatment $\times$ time interaction was apparent for any other biochemistry parameters prepartum.

Treatment had no effect $(P>0.1)$ on concentrations of serum BHB (Figure 2a), GLDH $(P=0.454)$ (Figure $2 \mathrm{~b}$ ), and glucose (Figure 2c) postpartum. However, cows on the silage-plus-concentrate treatment had a higher postcalving concentrations of serum total protein (60.7 and $64.9 \mathrm{~g} / \mathrm{L}$ for the silage-only and silage-plusconcentrate treatment, respectively; $\mathrm{SED}=1.61, P=$ $0.014)$ and urea (2.72 and $3.12 \mathrm{mM}$ for the silage-only and silage-plus-concentrate treatment, respectively; $\mathrm{SED}=0.152, P=0.011)$ and tended to have a higher concentrations of serum albumin $(25.8$ and $27.3 \mathrm{~g} / \mathrm{L}$ for the silage-only and silage-plus-concentrate treatment, respectively; $\mathrm{SED}=0.84, P=0.069)$, globulin $(34.9$ and $37.6 \mathrm{~g} / \mathrm{L}$ for the silage-only and silage-plus-concentrate treatment; respectively, $\mathrm{SED}=1.32, P=0.061$ ), and NEFA $(P=0.056)$ (Figure $2 \mathrm{~d})$ than cows on the silage-only treatment. Serum albumin $(\mathrm{SED}=0.74, P$ $<0.001)$, globulin $(\mathrm{SED}=1.19, P<0.001)$, glucose $(P$ $<0.001$ ) (Figure $2 \mathrm{c}$ ), and total protein $(\mathrm{SED}=1.70, P$ $<0.001)$ increased, and serum NEFA $(P<0.001)$ (Figure $2 \mathrm{a})$ and urea $(\mathrm{SED}=1.18, P<0.001)$ decreased

Table 3. Effects of concentrate supplementation during the dry period on prepartum and postpartum BW, $\mathrm{BCS}$, and energy balance (EB) parameters

\begin{tabular}{|c|c|c|c|c|}
\hline \multirow[b]{2}{*}{ Item } & \multicolumn{2}{|c|}{ Prepartum treatment } & \multirow[b]{2}{*}{$\mathrm{SED}^{1}$} & \multirow[b]{2}{*}{$P$-value } \\
\hline & $\begin{array}{l}\text { Silage } \\
\text { only }\end{array}$ & $\begin{array}{l}\text { Silage plus } \\
\text { concentrates }\end{array}$ & & \\
\hline \multicolumn{5}{|l|}{ Prepartum $^{2}$} \\
\hline Mean BW $(\mathrm{kg})$ & 647 & 682 & 5.7 & $<0.001$ \\
\hline BW change (kg) & +36 & +86 & 7.6 & $<0.001$ \\
\hline Mean BCS & 2.5 & 2.6 & 0.03 & 0.003 \\
\hline BCS change & +0.1 & +0.2 & 0.04 & 0.025 \\
\hline Mean daily EB (MJ/cow per dav) & 6.0 & 32.2 & 4.50 & $<0.001$ \\
\hline \multicolumn{5}{|l|}{ Postpartum $^{3}$} \\
\hline Mean BW $(\mathrm{kg})$ & 589 & 623 & 9.6 & $<0.001$ \\
\hline BW change to nadir $(\mathrm{kg})$ & -25 & -53 & 7.4 & $<0.001$ \\
\hline Days to nadir BW & 27 & 38 & 5.3 & 0.043 \\
\hline BW change to day $70(\mathrm{~kg})$ & 11 & -33 & 10.5 & $<0.001$ \\
\hline Mean BCS & 2.5 & 2.6 & 0.03 & 0.012 \\
\hline BCS change to day 70 & 0 & -0.1 & 0.03 & 0.016 \\
\hline Mean daily EB (MJ/cow per day) & -35.5 & -54.7 & 12.62 & 0.136 \\
\hline
\end{tabular}


(a)

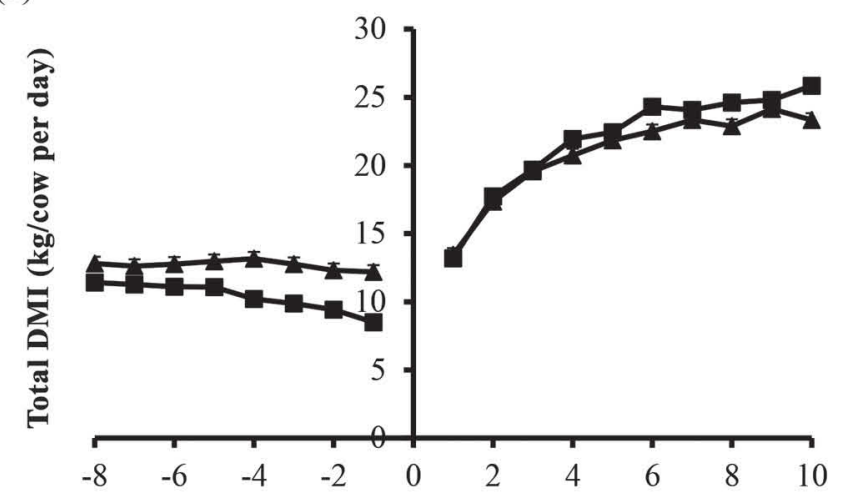

(c)

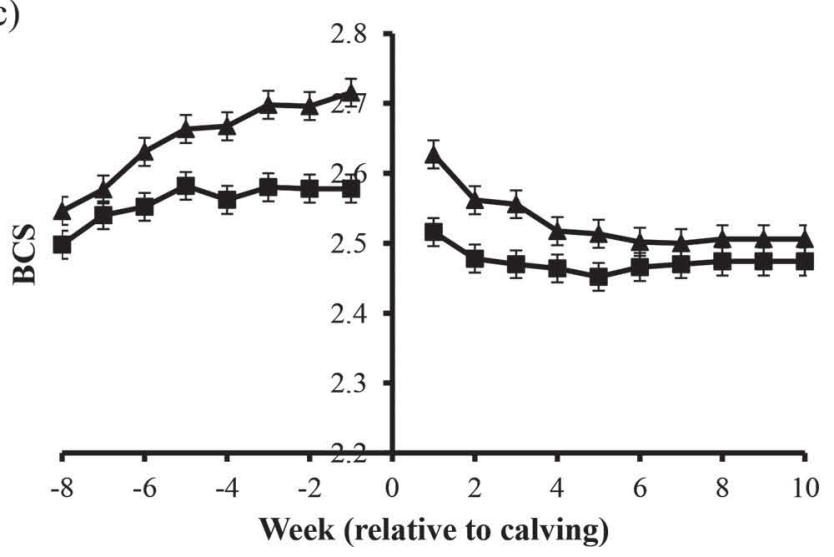

(b)

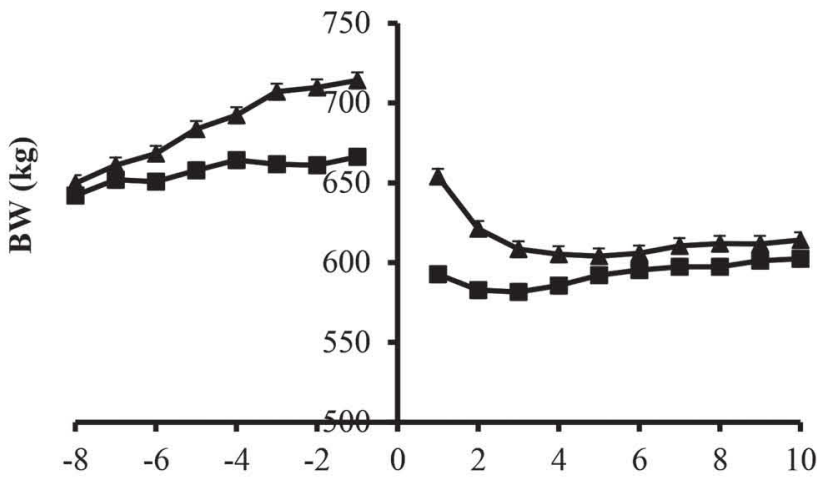

(d)

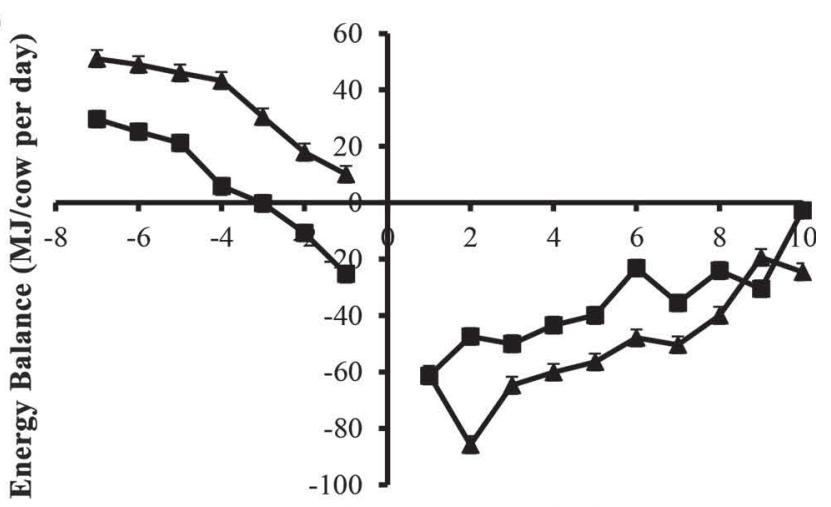

Week (relative to calving)

Figure 1. Effects of concentrate supplementation ( silage only, $\boldsymbol{\Delta}$ silage plus concentrates; error bars represent the standard error of the mean) during the dry period on prepartum and postpartum (a) total DMI [Prepartum: treatment, SE of the difference $(\mathrm{SED})=0.35, P<0.001 ;$ time, SED $=0.29, P<0.001$; treatment $\times$ time, $\mathrm{SED}=0.47, P=0.032$. Postpartum: treatment, SED $=0.66, P=0.232 ;$ time, SED $=0.60$, $P<0.001$; treatment $\times$ time, $\mathrm{SED}=0.95, P=0.027$; (b) BW (Prepartum: treatment, $\mathrm{SED}=4.7, P<0.001 ;$ time, SED $=3.7, P<0.001 ;$ treatment $\times$ time, $\mathrm{SED}=6.2, P<0.001$. Postpartum: treatment, $\mathrm{SED}=10.0, P<0.001 ;$ time, $\mathrm{SED}=3.3, P<0.001 ;$ treatment $\times$ time, SED $=8.0, P<0.001$ ); (c) BCS (Prepartum: treatment, $\mathrm{SED}=2.64, P=0.003$; time, $\mathrm{SED}=1.69, P<0.001 ;$ treatment $\times$ time, $\mathrm{SED}=2.98, P=$ 0.207. Postpartum: treatment, $\mathrm{SED}=2.65, P=0.010$; time, $\mathrm{SED}=1.29, P<0.001$; treatment $\times$ time, $\mathrm{SED}=2.55, P=0.186)$; and $(\mathrm{d})$ mean weekly energy balance (Prepartum: treatment, $\mathrm{SED}=3.04, P<0.001 ;$ time, $\mathrm{SED}=3.10, P<0.001 ;$ treatment $\times$ time, SED $=4.77, P=0.133$. Postpartum: treatment, $\mathrm{SED}=10.42, P=0.099$; time, $\mathrm{SED}=9.70, P=0.002$; treatment $\times$ time, $\mathrm{SED}=15.36, P=0.034)$.

during the postpartum period. A tendency existed for a postpartum treatment $\times$ time interaction with serum albumin (SED $=1.17, P=0.087)$, but no interaction $(P>0.1)$ was seen for any of the other parameters.

Treatment had no effect $(P>0.1)$ on the percentage of phagocytosis-positive neutrophils during wk -3 , 1 , or 2 (Figure $3 \mathrm{a}$ ) or on the phagocytic fluorescence intensity of neutrophils at wk -3 (Figure $3 \mathrm{~b}$ ). However, cows on the silage-plus-concentrate treatment had a higher phagocytic fluorescence intensity at wk $1(P$ $=0.005)$ and wk $2(P=0.026)$ postpartum compare with cows on the silage-only treatment. Dry period diet had no effect $(P>0.1)$ on the phagocytic index of neutrophils at wk -3 and 2 (Figure $3 \mathrm{c}$ ); however, cows on the silage-plus-concentrate treatment had a higher phagocytic index at wk $1(P=0.045)$ than those on the silage-only treatment. Treatment had no effect $(P>$
0.1 ) on the percentage of oxidative burst positive neutrophils (Figure 4a), the oxidative burst fluorescence intensity of neutrophils (Figure 4b), or on the oxidative burst index of neutrophils (Figure $4 \mathrm{c}$ ), at wk $-3,1$, or 2 relative to calving.

Treatment had no effect $(P>0.1)$ on either prepartum or postpartum serum Hp concentrations (Figure 3a), although concentrations increased during the prepartum period $(P=0.001)$ and decreased during the postpartum period $(P=0.005)$. No evidence $(P$ $>0.1$ ) existed for either a prepartum or postpartum treatment $\times$ time interaction for serum Hp (Figure 5a). Treatment had no effect $(P>0.1)$ on either prepartum or postpartum IFN- $\gamma$ production (Figure $5 \mathrm{~b}$ ). Although IFN- $\gamma$ production did not change $(P>0.1)$ during the prepartum period, IFN- $\gamma$ production increased during the postpartum period $(P=0.018)$. No evidence $(P$ 
$>0.1$ ) existed for a treatment $\times$ time interaction for IFN- $\gamma$ either prepartum or postpartum.

Treatment had no effect $(P>0.1)$ on the odds of obtaining a different vaginal mucus score at wk $1,2,3$, 4 , or 8 postpartum (Table 5). Similarly, treatment had no effect $(P>0.1)$ on days to onset of corpus luteal activity; cows with corpus luteal activity at $<42$ d; maximum progesterone concentration associated with the first corpus luteum; pregnancy rate to first service; pregnancy rate to first and second service; the percentage of cows treated at least once with progesterone, prostaglandin, or gonadotrophin releasing hormone; and the percentage of cows with clinical mastitis or retained fetal membranes (Table 6). However, a greater percentage $(P=0.008)$ of cows on the silage-plus-concentrate treatment were treated for lameness compared with cows on the silage-only treatment (Table 6).

Treatment had no effect on calf birth weight (40.2 and $40.7 \mathrm{~kg}$ for the silage-only and silage-plus-concentrate treatment, respectively; $\mathrm{SED}=1.75, P=0.796$ ) or calving difficulty (1.8 for both treatments; SED = $0.07, P=0.968)$.

\section{DISCUSSION}

The objective of the current study was to examine the performance, health, fertility, metabolic function, and immune function of dairy cows with "low" BCS at dry-off (mean 2.5), when offered a diet based on grass silage plus supplementary concentrates during the dry period. The diets offered are representative of those used within grassland-based dairy systems in many part of the world. With the silage-only treatment the prepartum diet supplied $106 \%$ of the cows ME requirements during the dry period, and the silageplus-concentrate treatment supplied $134 \%$ of cows ME requirements, based on the equations contained within Feed into Milk, the current UK dairy cow feed rationing system (Agnew et al., 2004).

\section{Prepartum Intake and Tissue Changes}

The higher prepartum DMI observed with cows offered concentrates during the prepartum period agrees with Keady et al. (2001) and McNamara et al. (2003b) and also with studies in which higher energy density TMR diets (versus lower energy density diets) were offered prepartum (Rabelo et al., 2003; Law et al., 2011; Zhang et al., 2015). However, in contrast to the findings of Keady et al. (2001) and McNamara et al. (2003b), no substitution of silage by concentrates was observed in the current study, despite the current study involving a higher quality silage, with higher quality silages normally associated with higher substitution rates. This finding may suggest that prepartum intakes were not limited by rumen capacity.

Total DMI with the silage-only and silage-plusconcentrate treatments were 11.4 and $12.8 \mathrm{~kg}$ during wk 8 prepartum and 8.5 and $12.2 \mathrm{~kg}$ during wk 1 prepartum, respectively. With the silage-only treatment, this outcome represents a $25 \%$ reduction in DMI across the dry period, with the majority of the decrease occurring during the 4 wk preceding calving. This decrease is broadly similar to the $32 \%$ decline in DMI described by

Table 4. Effects of concentrate supplementation during the dry period on prepartum and postpartum blood hematology

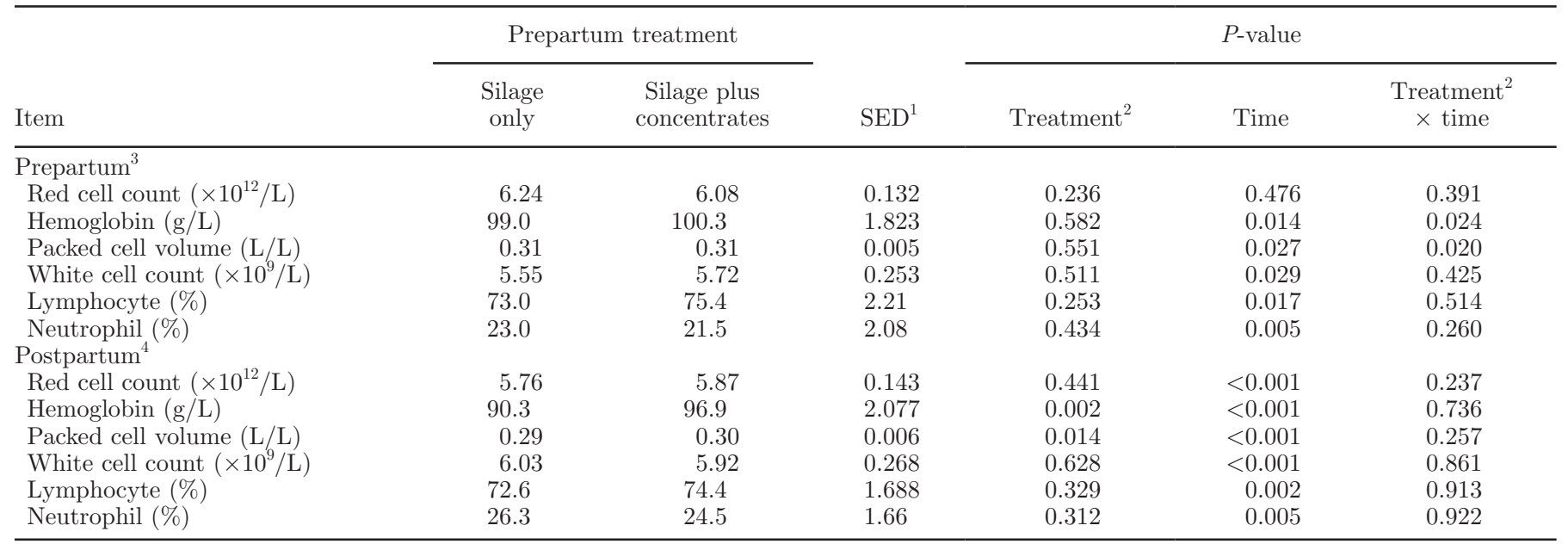

${ }^{1}$ Standard error of the difference for the effect of treatment.

${ }^{2}$ Prepartum treatment.

${ }^{3}$ Based on blood samples taken at wk 5,3 , and 1 prepartum.

${ }^{4}$ Based on blood samples taken during wk $2,4,6,8$, and 10 postpartum. 
(a)

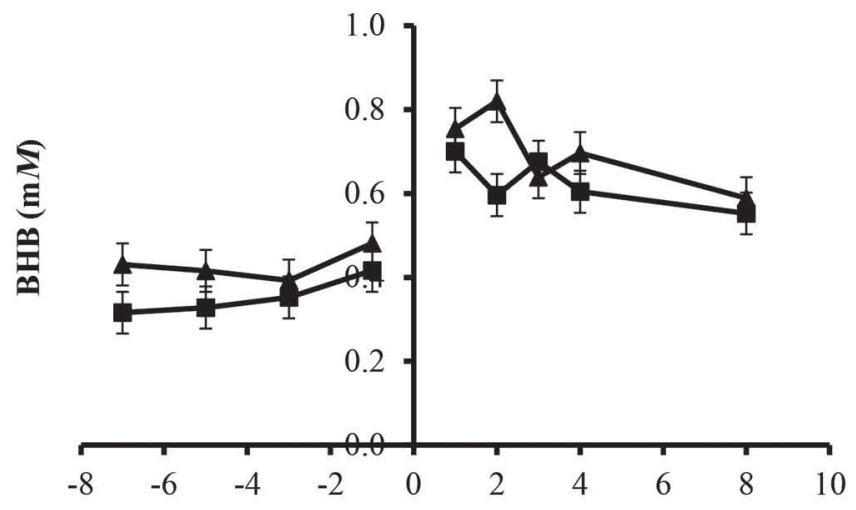

(c)

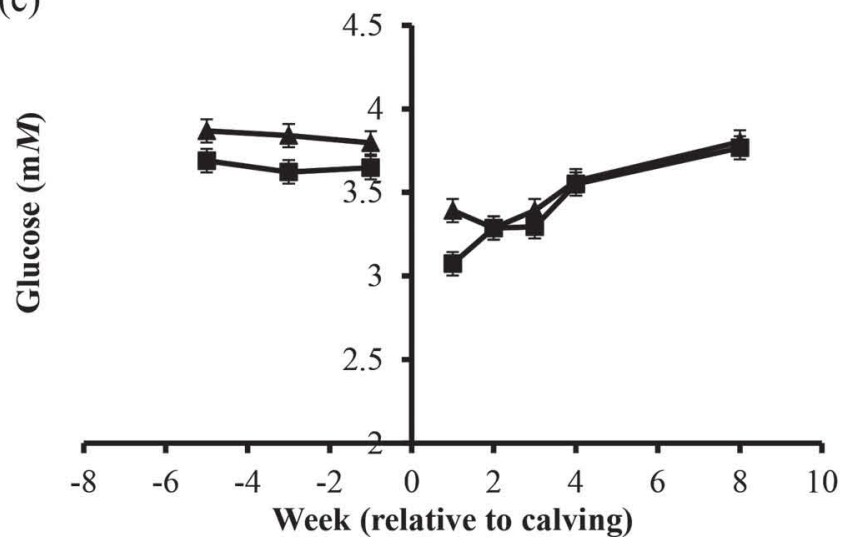

(b)

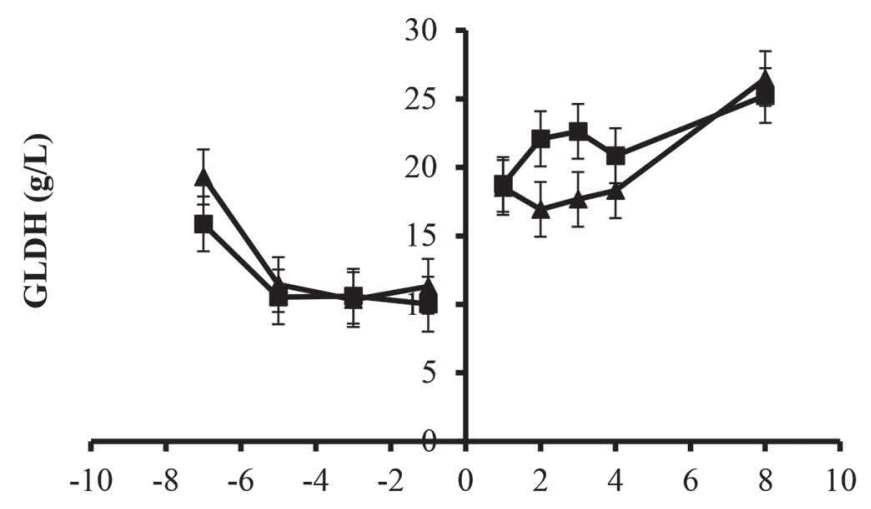

(d)

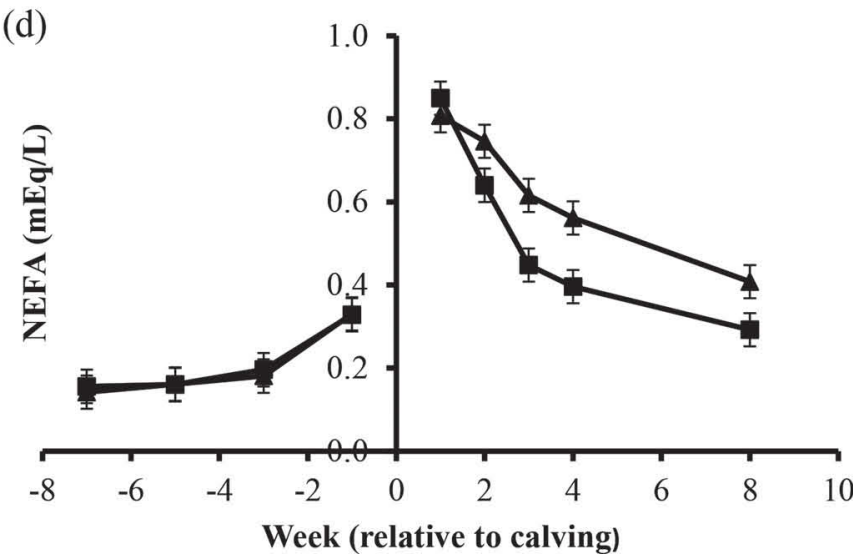

Figure 2. Effects of concentrate supplementation ( $\mathbf{\square}$ silage only, $\mathbf{\Delta}$ silage plus concentrates; error bars represent the standard error of the mean) during the dry period on prepartum and postpartum (a) mean weekly serum BHB concentration (Prepartum: treatment, SED $=0.03$, $P<0.001$; time, SED $=0.02, P<0.001$; treatment $\times$ time, SED $=0.03, P=0.276$. Postpartum: treatment, SED $=0.07, P=0.288 ;$ time, $\mathrm{SED}=0.07, P=0.402$; treatment $\times$ time, $\mathrm{SED}=0.11, P=0.275)$; (b) mean weekly serum glutamate dehydrogenase $(\mathrm{GLDH})$ concentration (Prepartum: treatment, SED $=2.52, P=0.499$; time, $\mathrm{SED}=1.97, P=0.001$; treatment $\times$ time, $\mathrm{SED}=3.19, P=0.836$. Postpartum: treatment, $\mathrm{SED}=2.64, P=0.454$; time, $\mathrm{SED}=3.55, P=0.318$; treatment $\times$ time, $\mathrm{SED}=5.13, P=0.883$ ); (c) mean weekly serum glucose concentration (Prepartum: treatment, $\mathrm{SED}=0.05, P=0.002$; time, $\mathrm{SED}=0.05, P=0.726$; treatment $\times$ time, $\mathrm{SED}=0.14, P=0.750 . \mathrm{Postpartum:}$ treatment, $\mathrm{SED}=0.07, P=0.176$; time, $\mathrm{SED}=0.10, P<0.001$; treatment $\times$ time, $\mathrm{SED}=0.14, P=0.452)$; and $(\mathrm{d})$ mean weekly serum nonesterified fatty acid (NEFA) concentration (Prepartum: treatment, SED $=0.02, P=0.796$; time, SED $=0.03, P<0.001 ;$ treatment $\times$ time, SED $=0.04, P=0.981$. Postpartum: treatment, $\mathrm{SED}=0.05, P=0.056$; time, $\mathrm{SED}=0.05, P<0.001 ;$ treatment $\times$ time, $\mathrm{SED}=0.07, P=0.255)$.

Hayirli et al. (2002) during the 3 wk preceding calving in a study involving 669 Holstein-Friesian cows offered a range of different diets. This decrease in total DMI during the dry period has also been observed in studies with cows offered silage-only diets (Keady et al., 2001; McNamara et al., 2003b) and can be attributed to changes in blood metabolite and hormone concentrations (Grummer et al., 2004) together with nutritional and neurological control mechanisms (Roche et al., 2013). In contrast, total DMI of cows on the silageplus-concentrate treatment decreased by $5 \%$ between wk 8 and 1 prepartum, with a similar lower decline observed when a grass silage diet was supplemented with concentrates (Keady et al., 2001) and when a more energy dense diet was offered during the close-up dry period (Vandehaar et al., 1999). In contrast, others have reported a less pronounced decrease in prepartum DMI when lower "controlled energy" diets were offered during the dry period, compared with diets that oversupplied energy (Vickers et al., 2013; Mann et al., 2015). The reasons for these inconsistent effects are unclear, although many factors (including circulating nutrient, metabolite and hormone concentrations) are known to regulate intake during late gestation (see review by Ingvartsen and Andersen, 2000).

Cows on the silage-plus-concentrate treatment gained more BW during the dry period than cows on the silage-only treatment. Although part of this gain is likely due to true body tissue gain, as reflected in a small but significantly greater increase in BCS (approximately 0.1 vs. 0.2 units of BCS gain with the silage-only and silage-plus-concentrate treatments, respectively, dur- 
ing the 8-wk dry period), rumen fill effects may also explain part of the increase in BW. This larger gain in prepartum BW and BCS are consistent with previous studies that involved an oversupply of energy prepar-
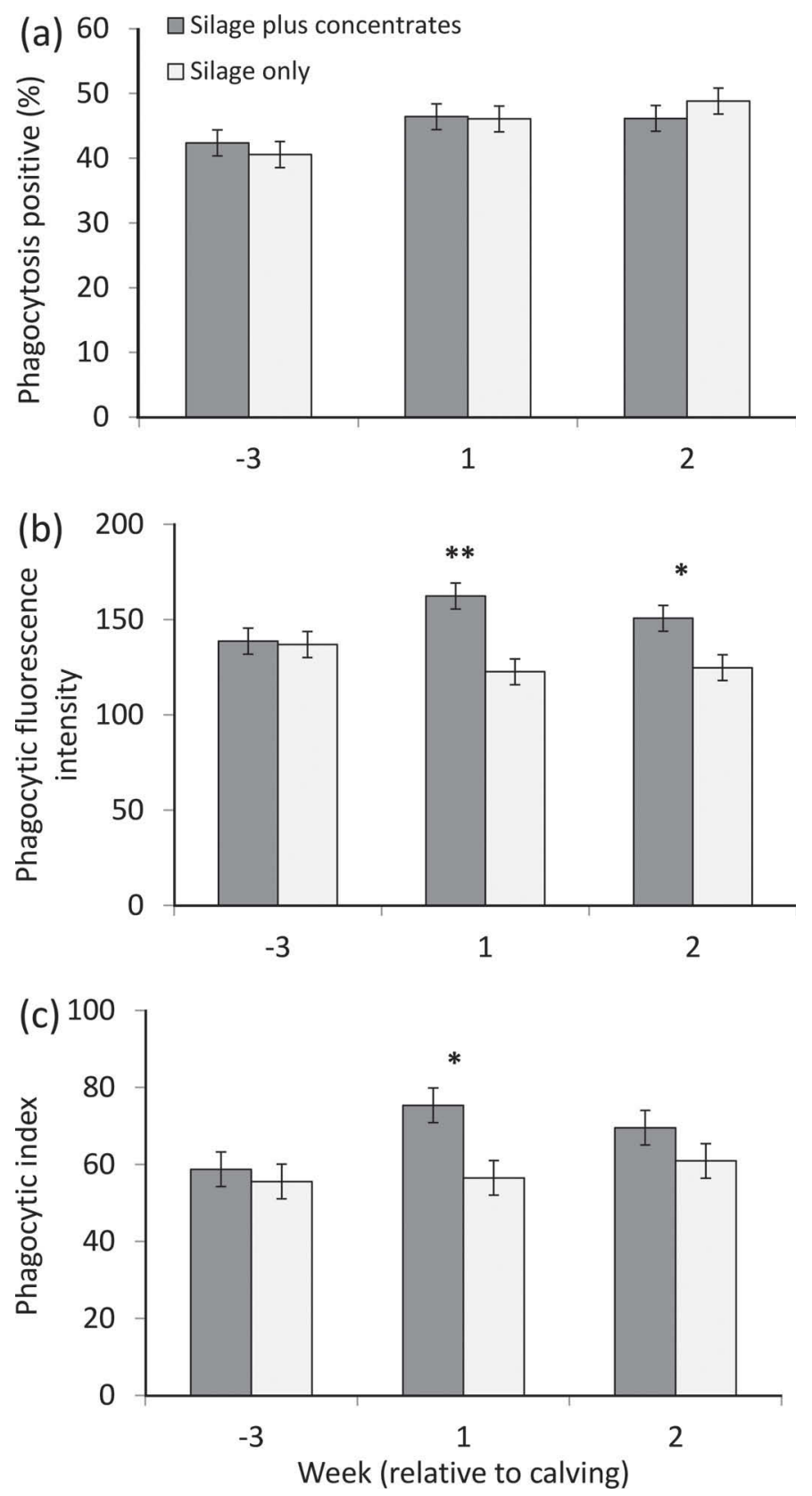

Figure 3. Effects of concentrate supplementation during the dry period on (a) mean percentage of phagocytosis positive neutrophils (wk $-3, \mathrm{SEM}=2.7, P=0.635$; wk 1 , SEM $=2.9, P=0.932$; wk 2, SEM $=2.9, P=0.502)$, (b) mean fluorescence intensity $(\times 1,000)$ of phagocytosis-positive neutrophils ( wk $-3, \mathrm{SEM}=12.1, P=0.919$; wk 1 , SEM $=9.4,{ }^{*} P=0.005 ;$ wk $\left.2, \mathrm{SEM}=7.9,{ }^{*} P=0.026\right)$, and $(\mathrm{c})$ mean phagocytic index of neutrophils $($ wk $-3, \mathrm{SEM}=7.4, P=0.825$; wk $1, \mathrm{SEM}=6.7,{ }^{*} P=0.045$; wk $\left.2, \mathrm{SEM}=5.7, P=0.467\right)$ at $\mathrm{wk}-3$, 1 , and 2 relative to calving. Data are presented as means with error bars representing the SEM. tum (Janovick and Drackley, 2010; Law et al., 2011; Zhang et al., 2015).

The higher prepartum DMI of cows on the silage-plusconcentrate treatment resulted in these cows having a higher EB during the dry period compared with those
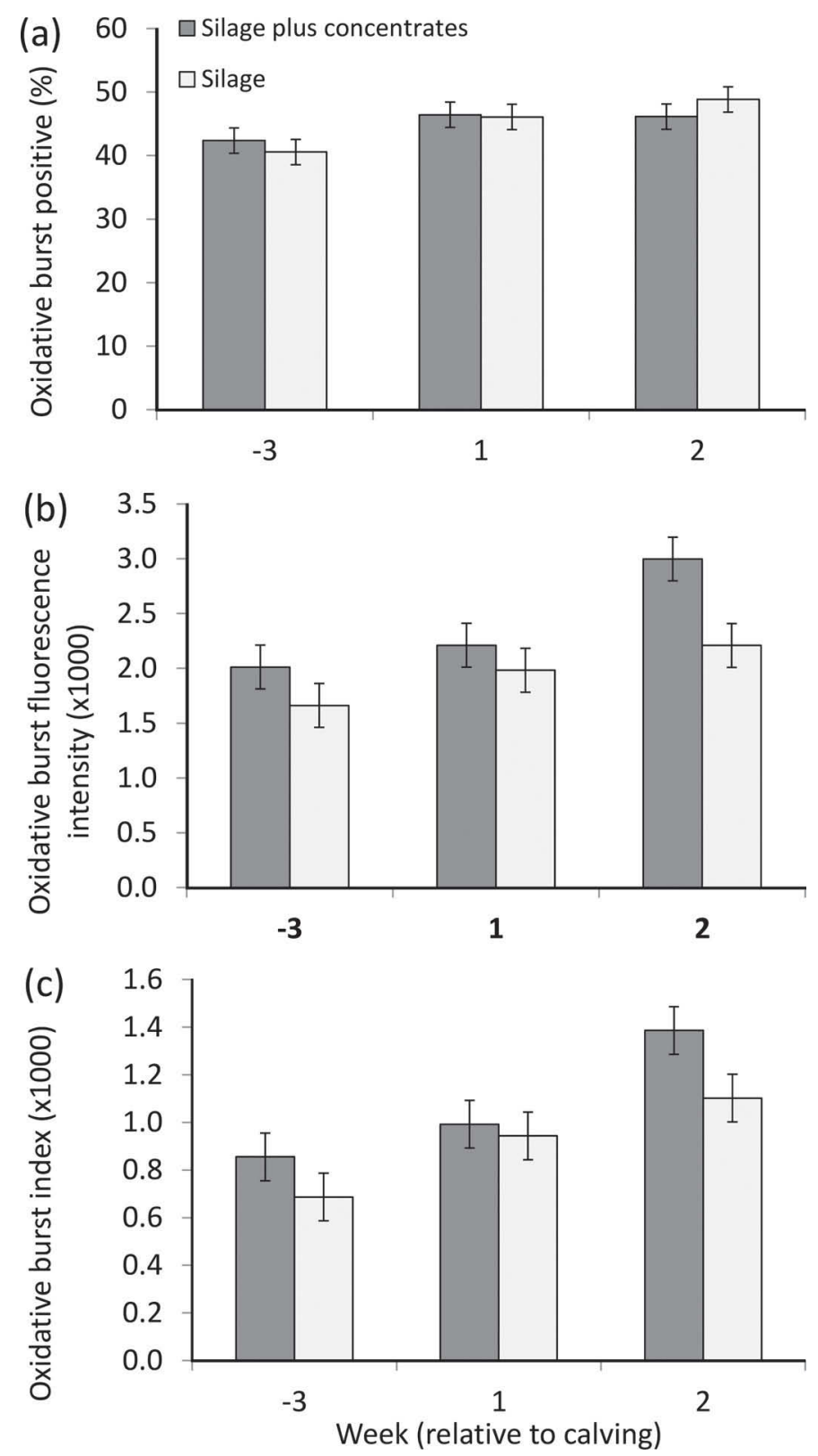

Figure 4. Effects of concentrate supplementation during the dry period on (a) mean percentage of oxidative burst positive neutrophils (wk -3 , SEM $=2.7, P=0.636$; wk $1, \mathrm{SEM}=2.9, P=0.932$; wk 2 , SEM $=2.9, P=0.502)$, (b) mean fluorescence intensity $(\times 1,000)$ of oxidative burst positive neutrophils ( wk $-3, \mathrm{SEM}=147, P=0.100$; wk $1, \mathrm{SEM}=249, P=0.517$; wk $2, \mathrm{SEM}=369, P=0.136)$, and $(\mathrm{c})$ mean oxidative burst index of neutrophils $(\times 1,000)(\mathrm{wk}-3, \mathrm{SEM}=$ $106, P=0.266$; wk $1, \mathrm{SEM}=135, P=0.797$; week $2, \mathrm{SEM}=183, P$ $=0.273)$ at wk $-3,1$, and 2 relative to calving. Data are presented as mean with error bars representing the SEM. 
on the silage-only treatment. However, EB decreased with both treatments throughout the dry period, especially during the 4 -wk period precalving. Cows on the silage-plus-concentrate treatment remained in positive $\mathrm{EB}$, but those on the silage-only treatment entered negative EB during the 2 wk preceding calving. The avoidance of prepartum negative EB with the silageplus-concentrate treatment may be desirable because negative EB contributes to peripartum immune suppression (Ingvartsen and Moyes, 2013), with Hammon et al. (2006) showing that negative EB prepartum was associated with decreased prepartum neutrophil function. This immune suppression is associated with an
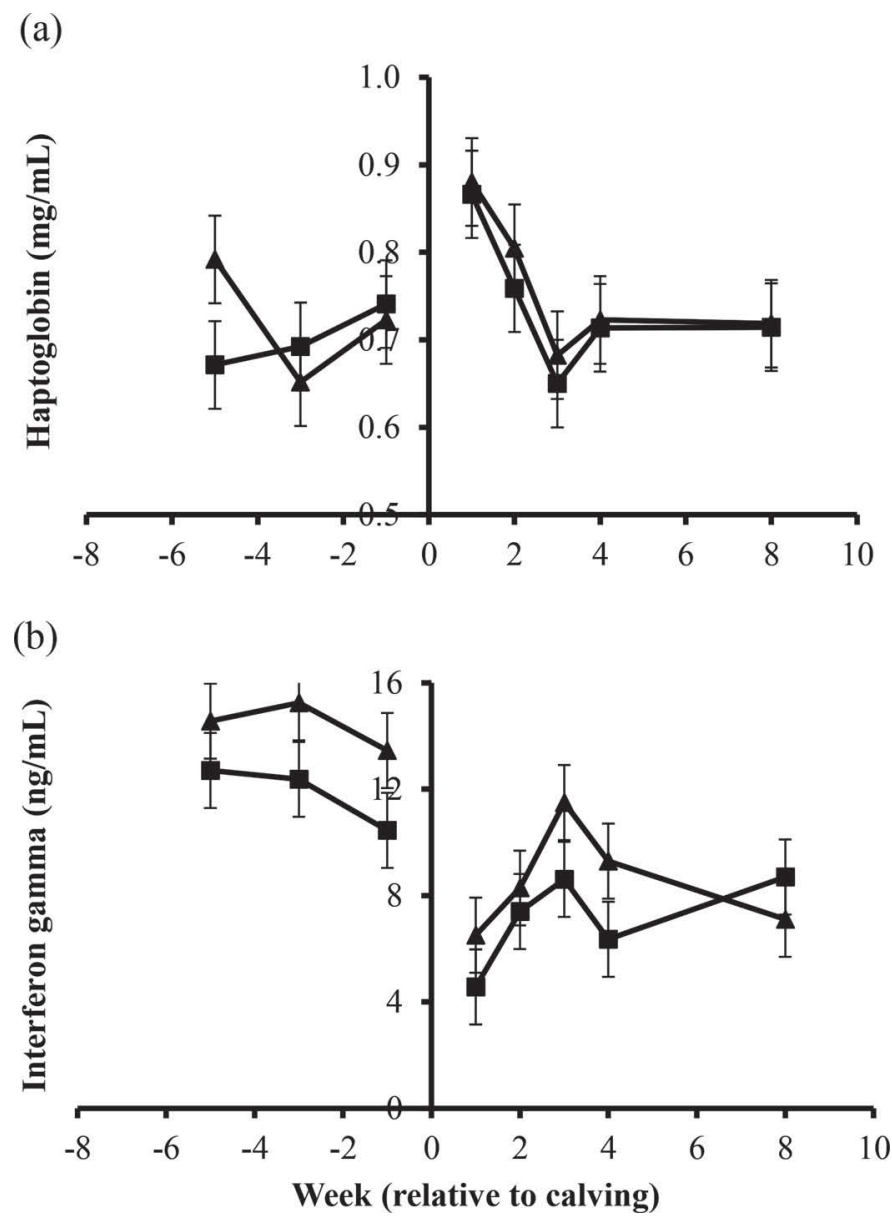

Figure 5. Effects of concentrate supplementation ( $\mathbf{\square}$ silage only, $\boldsymbol{\Delta}$ silage plus concentrates; error bars represent the standard error of the mean) during the dry period on prepartum and postpartum (a) mean serum haptoglobin concentration (Prepartum: treatment, SED $=0.09$, $P=0.752 ;$ time, SED $=0.11, P<0.001 ;$ treatment $\times$ time, SED $=$ $0.15, P=0.878$. Postpartum: treatment, $\mathrm{SED}=0.04, P=0.681$; time, $\mathrm{SED}=0.05, P=0.005$; treatment $\times$ time, $\mathrm{SED}=0.08, P=0.995$ ); and (b) mean IFN- $\gamma$ production of whole blood due to pokeweed mitogen stimulation (Prepartum: treatment, $\mathrm{SED}=2.03, P=0.217$; time, $\mathrm{SED}=1.22, P=0.255$; treatment $\times$ time, $\mathrm{SED}=2.18, P=0.890$. Postpartum: treatment, $\mathrm{SED}=1.10, P=0.290$; time, $\mathrm{SED}=1.74, P$ $=0.018 ;$ treatment $\times$ time, $\mathrm{SED}=1.94, P=0.472)$. increased risk of disease, with Kaneene et al. (1997) demonstrating a relationship between prepartum negative EB (and the associated fat mobilization) and an increased risk of metritis and retained placenta. The risk of production diseases, such as left-displaced abomasums, also increases with negative EB (Cameron et al., 1998). In addition, mean weekly EB declined by 55 and 41 MJ between wk 8 and 1 prepartum with the silage-only and silage-plus-concentrate treatment, respectively. The smaller decline with the latter treatment may also be desirable because large changes in EB before parturition (rather than the degree of negative EB) have been associated with an increased incidence of metabolic disorders in periparturient cows (Grummer et al., 2004).

Although cows on the silage-only treatment entered negative EB during the last 2 wk prepartum, serum NEFA concentrations were unaffected by treatment at this time, suggesting that the rate of lipolysis did not differ between treatments. This possibility is supported by the lack of evidence for a loss of BCS with cows on either treatment during this time. However, the higher mean serum BHB concentration with the silage-plusconcentrate treatment compared with the silage-only treatment is difficult to explain because elevated BHB concentrations are usually indicative of negative EB (Otter, 2013). The multitude of changes taking place during the dry period may mean that blood metabolic profiles at this time do not provide clear information on energy status. This interpretation agrees with the findings of McCarthy et al. (2015), who demonstrated a poor relationship between serum NEFA and BHB concentrations during the transition period and also showed that an elevated concentration of one of the metabolites does not always result in an elevated concentration of the other.

\section{Calving Measures, Postpartum Intake, Milk Production, and Tissue Changes}

In agreement with the findings of several other studies, prepartum diet had no effect on either calf birth weight (Douglas et al., 2006; Guo et al., 2007; Janovick and Drackley, 2010) or calving difficulty (Flipot et al., 1988; McNamara et al., 2003b; Janovick and Drackley, 2010). This absence of an effect is unsurprising because although a large part of fetal BW gain occurs during the last trimester of gestation, significant overfeeding during this time is required to cause significant fat deposition in the birth canal and an oversized fetus (Mee, 2008).

Cows with a higher BCS at calving are known to have a reduced postpartum DMI (Broster and Broster, 1998; Roche et al., 2009). Although postpartum DMI in 
Table 5. Effects of concentrate supplementation during the dry period on the probability (SE in parentheses) of obtaining a vaginal mucus score of $0,1, \geq 2$ during wk $1,2,3,4$, and 8 of lactation

\begin{tabular}{|c|c|c|c|c|}
\hline \multirow[b]{2}{*}{ Item } & \multicolumn{3}{|c|}{ Mucus score } & \multirow[b]{2}{*}{$P$-value } \\
\hline & 0 & 1 & $\geq 2$ & \\
\hline \multicolumn{5}{|l|}{ Week 1} \\
\hline Silage only & $0.15(0.206)$ & $0.28(0.158)$ & $0.58(0.132)$ & \\
\hline Silage plus concentrates & $0.20(0.165)$ & $0.31(0.175)$ & $0.48(0.139)$ & 0.488 \\
\hline \multicolumn{5}{|l|}{ Week 2} \\
\hline Silage only & $0.06(0.139)$ & $0.24(0.151)$ & $0.70(0.111)$ & \\
\hline Silage plus concentrates & $0.06(0.134)$ & $0.23(0.210)$ & $0.71(0.104)$ & 0.914 \\
\hline \multicolumn{5}{|l|}{ Week 3} \\
\hline Silage only & $0.24(0.192)$ & $0.36(0.146)$ & $0.39(0.163)$ & \\
\hline Silage plus concentrates & $0.19(0.159)$ & $0.34(0.179)$ & $0.47(0.139)$ & 0.539 \\
\hline \multicolumn{5}{|l|}{ Week 4} \\
\hline Silage only & $0.62(0.126)$ & $0.28(0.159)$ & $0.11(0.219)$ & \\
\hline Silage plus concentrates & $0.48(0.139)$ & $0.35(0.168)$ & $0.17(0.167)$ & 0.343 \\
\hline \multicolumn{5}{|l|}{ Week 8} \\
\hline Silage only & $0.96(0.04)$ & $0.04(0.04)$ & 0 & \\
\hline Silage plus concentrates & $0.92(0.05)$ & $0.08(0.05)$ & 0 & 0.525 \\
\hline
\end{tabular}

the current study was numerically almost $1 \mathrm{~kg}$ greater with the silage-only treatment, this difference was not significant and is consistent with the small difference (0.1 units) in BCS at calving between treatments. The lack of difference in postpartum DMI between treatments provides no support for the theory that offering concentrates during the dry period helps prepare the rumen for higher concentrate diets post calving. In addition, the absence of a treatment effect on postpartum intake is in agreement with studies in which prepartum energy intake for $100 \mathrm{~d}$ prepartum (Law et al., 2011), 8 wk prepartum (Dann et al., 2006; Janovick and Drack- ley, 2010; Mann et al., 2015), 4 wk prepartum (Keady et al., 2001; Rabelo et al., 2003; Dann et al., 2006), or 3 wk prepartum (Zhang et al., 2015) had no effect on postpartum intake.

No effect of dry cow diets on milk production was seen in the current study in common with the findings of Keady et al. (2001), Law et al. (2011), and Roche et al. (2015). However, cows on the silage-plusconcentrate treatment tended to produce milk with a higher fat concentration than those on the silage-only treatment, with a higher milk fat content in early lactation normally due to increased mobilization of fat

Table 6. Effects of concentrate supplementation during the dry period on measures of corpus luteum (CL) activity (based on milk progesterone), fertility outcomes, and fertility treatments and on the percentage of cows treated for various health disorders during the first $70 \mathrm{~d}$ of lactation

\begin{tabular}{|c|c|c|c|c|}
\hline \multirow[b]{2}{*}{ Item } & \multicolumn{2}{|c|}{ Prepartum treatment } & \multirow[b]{2}{*}{$\mathrm{SED}^{1}$} & \multirow[b]{2}{*}{$P$-value } \\
\hline & $\begin{array}{l}\text { Silage } \\
\text { only }\end{array}$ & $\begin{array}{l}\text { Silage plus } \\
\text { concentrates }\end{array}$ & & \\
\hline \multicolumn{5}{|l|}{ Corpus luteum measures } \\
\hline Days to onset of CL activity $^{2}$ & 36 & 38 & 4.3 & 0.702 \\
\hline Corpus luteal activity at $<42 \mathrm{~d}^{2}(\%$ of cows $)$ & 65.2 & 61.5 & 9.7 & 0.790 \\
\hline Maximum progesterone during the first CL $(\mathrm{ng} / \mathrm{mL})$ & 8.4 & 10.1 & 1.33 & 0.226 \\
\hline Pregnancy rate to first and second service & 59.1 & 56.5 & 14.7 & 0.862 \\
\hline \multicolumn{5}{|l|}{ Fertility treatments ( $\%$ of cows with at least one incident of) } \\
\hline Progesterone treatment & 12 & 23 & 10.5 & 0.295 \\
\hline Prostaglandin treatment & 44 & 38 & 13.8 & 0.688 \\
\hline GnRH treatment & 16 & 12 & 9.6 & 0.643 \\
\hline \multicolumn{5}{|l|}{ Percentage of cows with health disorders ${ }^{3}$} \\
\hline Clinical mastitis & 12 & 27 & 10.8 & 0.174 \\
\hline
\end{tabular}

${ }^{1}$ Standard error of the difference.

${ }^{2}$ Relative to calving date.

${ }^{3}$ Percentage of cows with at least one incident.

${ }^{4}$ Failure to pass the placenta within $24 \mathrm{~h}$. 
depots (Palmquist et al., 1993) and the direct uptake of serum NEFA by the mammary gland (Pullen et al., 1989). The tendency for a higher milk fat is explained by the greater postpartum tissue mobilization with the silage-plus-concentrate treatment, with several other studies having reported higher milk fat concentrations and greater mobilization of body tissue in cows offered concentrates during the dry period (Keady et al., 2001) and in cows oversupplied with energy during the dry period (Janovick and Drackley, 2010; Mann et al., 2015; Zhang et al., 2015). Nevertheless, the extent of tissue mobilization in the current study, even with the silageplus-concentrate treatment, was moderate compared with that reported in other studies. For example, cows on the silage-plus-concentrate treatment in the current study experienced a $\mathrm{BW}$ loss of $33 \mathrm{~kg}$ and a loss of 0.1 units BCS to $10 \mathrm{wk}$ postpartum, but those in a study by Janovick and Drackley (2010), which involved an oversupply of energy for the duration of the dry period, lost $88 \mathrm{~kg}$ and 0.8 BCS units until 8 wk postpartum. The relatively modest degree of tissue mobilization in the current study is likely to reflect the low (average of 2.6) BCS of cows at calving (versus 3.3 at calving in the study by Janovick and Drackley 2010) because cows with a higher BCS at calving lose more BCS postpartum than those with a lower BCS at calving (Broster and Broster, 1998). However, differences in postpartum fat mobilization between treatments in this study did not appear to affect hepatic function, with concentrations of GLDH, a liver-specific enzyme that increases due to hepatic insult and therefore provides an indirect measure of hepatic fat infiltration (Otter, 2013), unaffected by prepartum diet. Nevertheless, postpartum tissue mobilization with both treatments is reflected in the increased GLDH concentrations at this time compared with the dry period.

The increased tissue mobilization with the silageplus-concentrate treatment was reflected in a tendency for a greater negative EB with this treatment. This finding can be attributed to several factors, including the numerically lower DMI, the higher energy content of the milk produced, and the higher maintenance energy requirements due to cows being heavier (the latter a result of the larger prepartum weight gain). An increased negative EB when higher energy dense diets were offered prepartum has been observed in studies involving TMR diets (Agenäs et al., 2003; Douglas et al., 2006; Janovick and Drackley, 2010) and also studies that involve grazing cows (Roche et al., 2005, 2015).

Although many risk factors (nutritional, metabolic, environmental, and infectious) for lameness exist in dairy cows (Alban, 1995), Randall et al. (2015) identified a BCS loss in wk 0 to 4 postpartum as an important risk factor. Thus, the increased fat mobiliza- tion with the silage-plus-concentrate treatment in this study may have contributed to the higher incidence of postpartum lameness with this treatment. Bicalho et al. (2009) demonstrated a positive association between BCS and the digital cushion thickness, owing to the composition of the bovine digital cushion being mainly adipose tissue (Räber et al., 2004). In addition, studies have shown that the prevalence of sole ulcers and white line disease are higher in cows with a low digital cushion thickness because of the lower ability of the digital cushion to dampen the pressure exerted by the third phalanx on the soft tissue situated below (Bicalho et al., 2009).

\section{Inflammation, Immune Function, and Fertility}

Although the increased risk of disease during the peripartum period is recognized (Ingvartsen, 2006), it can be difficult to identify how management strategy affects binomially distributed health parameters, which are often multifactorial in their etiology, without enrolling large numbers of animals in studies (Grummer et al., 2004). However, the impact of management strategy on susceptibility to infection can be assessed with fewer animals by examining immune function. Several approaches were adopted within the current study, including an assessment of inflammatory measures (serum Hp concentrations and hematology) and immune function tests involving both the innate (neutrophil function) and acquired (IFN- $\gamma$ ) immune system branches.

Serum Hp, a positive acute phase protein synthesized by hepatocytes (Huzzey et al., 2009), increases in response to many inflammatory stimuli (Bertoni et al., 2008) including infection, inflammation, surgical trauma (Murata et al., 2004), chronic subclinical mastitis (Grönlund et al., 2005), metritis (Huzzey et al., 2009), hepatic lipidosis (Ametaj et al., 2005), lameness (Smith et al., 2010), and metabolic stress (Hiss et al., 2009). Although the prepartum treatments had no overall effect on either prepartum or postpartum serum Hp concentrations, they did peak at wk 1 postpartum and decrease until wk 3 postpartum. This finding is broadly in agreement with the study by Huzzey et al. (2009), who observed peak Hp concentrations during wk 1 postpartum before a gradual decline to between 12 and $21 \mathrm{~d}$ postpartum. The finding also accords with the review findings by LeBlanc (2012), who stated that Hp concentrations generally decrease from calving to 2 wk postpartum. Although increased negative EB has been correlated with increased serum $\mathrm{Hp}$ in previous studies (Bionaz et al., 2007; Moyes et al., 2009), no such response was observed in the current study, despite the tendency for a greater negative EB with the silageplus-concentrate treatment. Therefore, Hp data provide 
no evidence that offering concentrates during the dry period had an effect on either clinical or subclinical inflammatory, infectious, or metabolic conditions.

Inflammatory responses during periods of stress can also be reflected in an increase in total white blood cell count (leukocytosis), a high neutrophil count (neutrophilia), and a low lymphocyte count (lymphopenia; Cole et al., 1997; Otter, 2013). Although leukocytosis, neutrophilia, and lymphopenia were observed around the time of calving in the current study, which is consistent with the rise in serum $\mathrm{Hp}$ concentration at the same time, mean data with both treatments remained within normal physiological parameters for cattle (as reported by Agri-Food and Biosciences Institute, Veterinary Sciences Division, Belfast), indicating that this was not a true stress leukogram. The absence of a difference between treatments in white cell measures is also consistent with the absence of a treatment effect on serum Hp concentrations. Although cows on the silage-plus-concentrate treatment had a higher mean hemoglobin concentration and packed cell volume than those on the silage-only treatment, the differences between treatments were small, suggesting a negligible difference in red blood cell function, with all values within normal physiological parameters (Agri-Food and Biosciences Institute, Veterinary Sciences Division).

The functional capacity of blood neutrophils was examined during the transition period because neutrophils are the leukocytes that provide the primary line of cellular defense against bacterial infections such as mastitis (Paape et al., 2003) and metritis (Hussain, 1989), which are important infectious diseases during the transition period. Although prepartum treatment had no effect on the percentage of phagocytosispositive neutrophils, the active neutrophils from cows on the silage-plus-concentrate treatment had a higher mean phagocytic activity as measured by fluorescence intensity at week 1 and 2 postpartum than those from cows on the silage-only treatment. The higher serum glucose concentration with the silage-plus-concentrate treatment may help explain this effect because glucose (and its storage form glycogen) is the preferred fuel for neutrophil activity (Borregaard and Herlin, 1982; Pithon-Curi et al., 2004; Kim et al., 2005). This higher phagocytic index with the silage-plus-concentrate treatment occurred despite an increased degree of tissue mobilization with this treatment. Adipose tissue mobilization is usually associated with a decrease in neutrophil function because of the detrimental impact of serum NEFA (Hammon et al., 2006; Scalia et al., 2006) and BHB (Suriyasathaporn et al., 2000) concentrations. However, serum NEFA and BHB concentrations did not differ during wk 1 in the current study.
Neutrophil function has been shown to decline during the transition period (Kehrli et al., 1989; Gilbert et al., 1993; Mallard et al., 1998), with activity gradually decreasing from 3 wk prepartum (Gilbert et al., 1993; Kimura et al., 1999) reaching a nadir within a few days either before (Kimura et al., 1999) or after (Gilbert et al., 1993) parturition and remaining low for approximately 15 d postpartum (Gilbert et al., 1993; Kimura et al., 1999), before increasing through to at least 6 wk postpartum (Gilbert et al., 1993). The absence of a peripartum depression in neutrophil activity in the current study (based on phagocytic and oxidative burst measurements) agrees in part with the findings of Llamas Moya et al. (2008). In their study, which also involved cows offered a grass silage-based ration, no peripartum impairment of phagocytic activity was observed, although the percentage of oxidative burst positive neutrophils decreased at d 14 postpartum. The relatively short measurement period adopted in the current study may also have made the periparturient depression in activity difficult to identify.

Neutrophil function provides the primary line of cellular defense against bacterial infections such as mastitis (Paape et al., 2003) and metritis (Hussain, 1989), but prepartum treatment had no effect on the incidence of either disease. This outcome suggests that diet had no effect on the susceptibility to infectious organisms responsible for clinical mastitis and supports the findings of Mashek and Beede (2001) and Dann et al. (2006). In addition, the absence of an effect of prepartum treatments on SCS indicates no difference in udder health and the susceptibility to the contagious organisms responsible for subclinical mastitis, in agreement with Hayirli et al. (2011) and Mann et al. (2015). In addition, retained fetal membranes occur because of the failure of the immune system to successfully break down the cotyledon-caruncle attachment (LeBlanc, 2008), with Kimura et al. (2002) demonstrating that neutrophils from cows with retained fetal membranes had impaired neutrophil activity both before and after calving. The incidence of retained fetal membranes was unaffected by precalving diet, which agrees with the findings of Vandehaar et al. (1999) and suggests no difference in uterine immune function existed between treatments.

Pokeweed mitogen was used in a whole blood culture to examine the functional reactiveness of lymphocytes to produce the cytokine IFN- $\gamma$. Increased IFN- $\gamma$ production results in a heightened immune surveillance and function during infection (Schroder et al., 2004), and reduced production is associated with increased susceptibility to infectious diseases (Kehrli and Harp, 2001; Nonnecke et al., 2003). Although prepartum 
nutrition had no effect on the overall ability of in vitro PWM-stimulated lymphocytes to produce IFN- $\gamma$, either prepartum or postpartum, the lower production after calving with both treatments indicates reduced immunocompetence at this time, in agreement with the findings of Lessard et al. (2004) and O'Driscoll et al. (2012). This result may be due in part to high serum Hp concentrations at this time having a suppressive effect on lymphocyte activity (Murata and Miyamoto, 1993). Heiser et al. (2015) reported a decrease in IFN- $\gamma$ mRNA expression at week 1 postpartum, which then "overshoots" at week 2, before adjusting to prepartum levels at week 3. Although IFN- $\gamma$ was measured by ELISA in the current study, a similar effect was observed with an overshoot of IFN- $\gamma$ production at week 3 postpartum, though concentrations at week 4 or 8 did not fully recover to prepartum levels. Although increasing serum NEFA concentrations have been shown to be negatively correlated with IFN- $\gamma$ production in overconditioned cows, this relationship was absent in thin cows (Lacetera et al., 2005). No such effect was observed in the current study, despite a trend for a higher serum NEFA concentration in the silage-plusconcentrate treatment, with this result likely a reflection of the low BCS of the cows in this study.

Dairy cow fertility is known to be influenced by many factors, including genetics, nutrition, and management, and in a review of fertility in high-yielding dairy cows, Walsh et al. (2011) ranked the ability to resolve bacterial infection in the postpartum uterus as having the greatest effect on fertility outcomes. Bacterial contamination of the uterus following parturition is an inevitable and normal consequence of calving, with up to $100 \%$ of cows affected in some studies (Sheldon et al., 2006, 2008), and an effective immune response is crucial to ensuring a resolution of infection and limiting the negative impact of uterine disease on fertility (Sheldon et al., 2008). Vaginal mucus scores are used to provide an indirect assessment of severity of bacterial infection in the uterus and the associated inflammatory response (Williams et al., 2005), with scores in the current study providing no evidence that prepartum nutrition affected uterine infection. This outcome may have contributed to the absence of a treatment effect on corpus luteum measures and the observed fertility outcomes. Similarly, other studies have found no evidence that dry period nutrition influenced fertility performance (Keady et al., 2001; McNamara et al., 2003a; Roche et al., 2015). In addition, although peripartum negative EB is known to have a negative impact on follicular development and interval to first ovulation and to reduce corpus luteum progesterone concentrations with an overall reduction in fertility (Butler, 2003), the tendency for cows on the silage-plus-concentrate treat- ments to have a greater negative EB post calving did not affect fertility outcomes. Similarly, in a separate study involving more than 1,200 cows offered grass silage-based diets on 10 Northern Ireland dairy farms [R. A. Law (Agri-Food and Biosciences Institute, Hillsborough, Northern Ireland) and C. P. Ferris, unpublished data], fertility outcomes did not differ in cows offered no concentrates during the dry period compared with those offered concentrates for either 3 wk preceding calving or throughout the entire dry period.

\section{CONCLUSIONS}

This study demonstrated that when Holstein-Friesian cows with relatively low BCS were supplemented with concentrates in addition to a grass silage diet during the dry period, they experienced greater BW and BCS gain prepartum, greater BW and BCS loss postpartum, tended to have a higher milk fat concentration and serum NEFA concentration postpartum, and had an increased incidence of lameness. However, DMI and milk yield postpartum were not affected. Despite this larger postpartum body tissue loss, cows receiving additional concentrates had a higher neutrophil function during wk 1 postpartum, as measured by phagocytic index, with this likely due to both the higher serum glucose concentration and lack of difference in serum NEFA concentration at this time. This improved neutrophil function at wk 1 postpartum did not result in lower incidence of infectious disease.

\section{ACKNOWLEDGMENTS}

This study was cofunded by the Department of Agriculture and Rural Development in Northern Ireland and by AgriSearch (farmer levy). Thanks are due to the Dairy Unit staff at the AFBI Hillsborough for care of the experimental animals and for assisting with experimental measurements, the laboratory staff in AFBI Hillsborough for undertaking milk and feed analysis, and to the staff in AFBI Veterinary Sciences Division for assisting with blood analysis. Mark Little acknowledges the receipt of a PhD studentship from AgriSearch.

\section{REFERENCES}

Agenäs, S., E. Burstedt, and K. Holtenius. 2003. Effects of feeding intensity during the dry period. 1. Feed intake, body weight, and milk production. J. Dairy Sci. 86:870-882.

Agnew, R. E., T. Yan, J. France, E. Kebreab, and C. Thomas. 2004. Feed into Milk. A New Applied Feeding System for Dairy Cows. Nottingham University Press, Nottingham, UK.

Alban, L. 1995. Lameness in Danish dairy cows: Frequency and possible risk factors. Prev. Vet. Med. 22:213-225. 
Ametaj, B. N., B. J. Bradford, G. Bobe, R. A. Nafikov, Y. Lu, J. W. Young, and D. C. Beitz. 2005. Strong relationships between mediators of the acute phase response and fatty liver in dairy cows. Can. J. Anim. Sci. 85:165-175.

Andersen, J. B., J. Sehested, and K. L. Ingvartsen. 1999. Effect of dry cow feeding strategy on rumen $\mathrm{pH}$, concentration of volatile fatty acids and rumen epithelium development. Acta Agric. Scand. Anim. Sci. 49:149-155.

Bell, A. W. 1995. Regulation of organic nutrient metabolism during transition from late pregnancy to early lactation. J. Anim. Sci. 73:2804-2819.

Bertoni, G., E. Trevisi, X. Han, and M. Bionaz. 2008. Effects of inflammatory conditions on liver activity in puerperium period and consequences for performance in dairy cows. J. Dairy Sci. 91:33003310 .

Bicalho, R. C., V. S. Machado, and L. S. Caixeta. 2009. Lameness in dairy cattle: A debilitating disease or a disease of debilitated cattle? A cross-sectional study of lameness prevalence and thickness of the digital cushion. J. Dairy Sci. 92:3175-3184.

Bionaz, M., E. Trevisi, L. Calamari, F. Librandi, A. Ferrari, and G. Bertoni. 2007. Plasma paraoxonase, health, inflammatory conditions, and liver function in transition dairy cows. J. Dairy Sci. 90:1740-1750

Bobe, G., J. W. Young, and D. C. Beitz. 2004. Invited review: Pathology, etiology, prevention, and treatment of fatty liver in dairy cows. J. Dairy Sci. 87:3105-3124.

Borregaard, N., and T. Herlin. 1982. Energy metabolism of human neutrophils during phagocytosis. J. Clin. Invest. 70:550-557.

Bradley, A. J., and M. J. Green. 2004. The importance of the nonlactating period in the epidemiology of intramammary infection and strategies for prevention. Vet. Clin. North Am. Food Anim. Pract. 20:547-568.

Broster, W. H., and V. J. Broster. 1998. Body score of dairy cows. J. Dairy Res. 65:155-173.

Butler, W. R. 2003. Energy balance relationships with follicular development, ovulation and fertility in postpartum dairy cows. Livest. Prod. Sci. 83:211-218.

Cameron, R. E. B., P. B. Dyk, T. H. Herdt, J. B. Kaneene, R. Miller, H. F. Bucholtz, J. S. Liesman, M. J. Vandehaar, and R. S. Emery. 1998. Dry cow diet, management, and energy balance as risk factors for displaced abomasum in high producing dairy herds. J. Dairy Sci. 81:132-139.

Cole, D. J., A. J. Roussel, and M. S. Whitney. 1997. Interpreting a bovine CBC: Evaluating the leukon and acute-phase proteins. Vet. Med. 92:470-478.

Cushnahan, A., and F. J. Gordon. 1995. The effects of grass preservation on intake, apparent digestibility and rumen degradation characteristics. Anim. Sci. 60:429-438.

Dann, H. M., N. B. Litherland, J. P. Underwood, M. Bionaz, A. D'Angelo, J. W. McFadden, and J. K. Drackley. 2006. Diets during far-off and close-up dry periods affect periparturient metabolism and lactation in multiparous cows. J. Dairy Sci. 89:3563-3577.

Dann, H. M., G. A. Varga, and D. E. Putnam. 1999. Improving energy supply to late gestation and early postpartum dairy cows. J. Dairy Sci. 82:1765-1778.

Dirksen, G. U., H. G. Liebich, and E. Mayer. 1985. Adaptive changes of the ruminal mucosa and their functional and clinical significance. Bovine Pract. 20:116-120.

Douglas, G. N., T. R. Overton, H. G. Bateman Ii, H. M. Dann, and J. K. Drackley. 2006. Prepartal plane of nutrition, regardless of dietary energy source, affects periparturient metabolism and dry matter intake in Holstein cows. J. Dairy Sci. 89:2141-2157.

Drackley, J. K. 1999. Biology of dairy cows during the transition period: The final frontier? J. Dairy Sci. 82:2259-2273.

Drackley, J. K., and F. C. Cardoso. 2014. Prepartum and postpartum nutritional management to optimize fertility in high-yielding dairy cows in confined TMR systems. Animal 8(Suppl. 1):5-14.

Edmonson, A. J., I. J. Lean, L. D. Weaver, T. Farver, and G. Webster. 1989. A body condition scoring chart for Holstein dairy cows. J. Dairy Sci. 72:68-78.
Farm Animal Welfare Council. 1997. Report on the Welfare of Dairy Cattle. Ministry of Agriculture, Fisheries, and Food, Tolworth/ Surbiton, Surrey, UK.

Flipot, P. M., G. L. Roy, and J. J. Dufour. 1988. Effect of peripartum energy concentration on production performance of Holstein cows. J. Dairy Sci. 71:1840-1850.

Friggens, N. C., J. B. Andersen, T. Larsen, O. Aaes, and R. J. Dewhurst. 2004. Priming the dairy cow for lactation: A review of dry cow feeding strategies. Anim. Res. 53:453-473.

Gilbert, R. O., Y. T. Gröhn, P. M. Miller, and D. J. Hoffman. 1993. Effect of parity on periparturient neutrophil function in dairy cows. Vet. Immunol. Immunopathol. 36:75-82.

Goff, J. P., and R. L. Horst. 1997. Physiological changes at parturition and their relationship to metabolic disorders. J. Dairy Sci. 80:1260-1268.

Grönlund, U., C. H. Sandgren, and K. P. Waller. 2005. Haptoglobin and serum amyloid A in milk from dairy cows with chronic subclinical mastitis. Vet. Res. 36:191-198.

Grummer, R. R. 1995. Impact of changes in organic nutrient metabolism on feeding the transition dairy cow. J. Anim. Sci. 73:28202833

Grummer, R. R., D. G. Mashek, and A. Hayirli. 2004. Dry matter intake and energy balance in the transition period. Vet. Clin. North Am. Food Anim. Pract. 20:447-470.

Guo, J., R. R. Peters, and R. A. Kohn. 2007. Effect of a transition diet on production performance and metabolism in periparturient dairy cows. J. Dairy Sci. 90:5247-5258.

Hammon, D. S., I. M. Evjen, T. R. Dhiman, J. P. Goff, and J. L. Walters. 2006. Neutrophil function and energy status in Holstein cows with uterine health disorders. Vet. Immunol. Immunopathol. 113:21-29

Hayirli, A., R. R. Grummer, E. V. Nordheim, and P. M. Crump. 2002. Animal and dietary factors affecting feed intake during the prefresh transition period in Holsteins. J. Dairy Sci. 85:3430-3443.

Hayirli, A., D. H. Keisler, and L. Doepel. 2011. Peripartum responses of dairy cows to prepartal feeding level and dietary fatty acid source. J. Dairy Sci. 94:917-930.

Heiser, A., A. McCarthy, N. Wedlock, S. Meier, J. Kay, C. Walker, M. A. Crookenden, M. D. Mitchell, S. Morgan, K. Watkins, J. J. Loor, and J. R. Roche. 2015. Grazing dairy cows had decreased interferon-gamma, tumor necrosis factor, and interleukin-17, and increased expression of interleukin-10 during the first week after calving. J. Dairy Sci. 98:937-946.

Hernandez-Urdaneta, A., C. E. Coppock, R. E. McDowell, D. Gianola, and N. E. Smith. 1976. Changes in forage-concentrate ratio of complete feeds for dairy cows. J. Dairy Sci. 59:695-707.

Hiss, S., C. Weinkauf, S. Hachenberg, and H. Sauerwein. 2009. Short communication: Relationship between metabolic status and the milk concentrations of haptoglobin and lactoferrin in dairy cows during early lactation. J. Dairy Sci. 92:4439-4443.

Hussain, A. M. 1989. Bovine uterine defense mechanisms: A review. Zentralbl. Veterinarmed. B 36:641-651.

Huzzey, J. M., T. F. Duffield, S. J. LeBlanc, D. M. Veira, D. M. Weary, and M. A. G. von Keyserlingk. 2009. Short communication: Haptoglobin as an early indicator of metritis. J. Dairy Sci. 92:621-625.

Ingvartsen, K. L. 2006. Feeding- and management-related diseases in the transition cow: Physiological adaptations around calving and strategies to reduce feeding-related diseases. Anim. Feed Sci. Technol. 126:175-213.

Ingvartsen, K. L., and J. B. Andersen. 2000. Integration of metabolism and intake regulation: A review focusing on periparturient animals. J. Dairy Sci. 83:1573-1597.

Ingvartsen, K. L., R. J. Dewhurst, and N. C. Friggens. 2003. On the relationship between lactational performance and health: Is it yield or metabolic imbalance that cause production diseases in dairy cattle? A position paper. Livest. Prod. Sci. 83:277-308.

Ingvartsen, K. L., and K. Moyes. 2013. Nutrition, immune function and health of dairy cattle. Animal 7(Suppl. 1):112-122.

Janovick, N. A., and J. K. Drackley. 2010. Prepartum dietary management of energy intake affects postpartum intake and lactation 
performance by primiparous and multiparous Holstein cows. J. Dairy Sci. 93:3086-3102.

Johnson, D. G., and D. E. Otterby. 1981. Influence of dry period diet on early postpartum health, feed intake, milk production, and reproductive efficiency of Holstein cows. J. Dairy Sci. 64:290-295.

Kaneene, J. B., R. Miller, T. H. Herdt, and J. C. Gardiner. 1997. The association of serum nonesterified fatty acids and cholesterol, management and feeding practices with peripartum disease in dairy cows. Prev. Vet. Med. 31:59-72.

Keady, T. W. J., C. S. Mayne, D. A. Fitzpatrick, and M. A. McCoy. 2001. Effect of concentrate feed level in late gestation on subsequent milk yield, milk composition, and fertility of dairy cows. J. Dairy Sci. 84:1468-1479.

Kehrli, M. E., Jr., and J. A. Harp. 2001. Immunity in the mammary gland. Vet. Clin. North Am. Food Anim. Pract. 17:495-516, vi.

Kehrli, M. E., Jr., B. J. Nonnecke, and J. A. Roth. 1989. Alterations in bovine neutrophil function during the periparturient period. Am. J. Vet. Res. 50:207-214.

Kim, I.-H., K.-J. Na, and M.-P. Yang. 2005. Immune responses during the peripartum period in dairy cows with postpartum endometritis. J. Reprod. Dev. 51:757-764

Kimura, K., J. P. Goff, and M. E. Kehrli Jr. 1999. Effects of the presence of the mammary gland on expression of neutrophil adhesion molecules and myeloperoxidase activity in periparturient dairy cows. J. Dairy Sci. 82:2385-2392.

Kimura, K., J. P. Goff, M. E. Kehrli Jr., and T. A. Reinhardt. 2002. Decreased neutrophil function as a cause of retained placenta in dairy cattle. J. Dairy Sci. 85:544-550.

Lacetera, N., D. Scalia, U. Bernabucci, B. Ronchi, D. Pirazzi, and A. Nardone. 2005. Lymphocyte functions in overconditioned cows around parturition. J. Dairy Sci. 88:2010-2016.

Law, R. A., F. J. Young, D. C. Patterson, D. J. Kilpatrick, A. R. G. Wylie, K. L. Ingvarsten, A. Hameleers, M. A. McCoy, C. S. Mayne, and C. Ferris. 2011. Effect of precalving and postcalving dietary energy level on performance and blood metabolite concentrations of dairy cows throughout lactation. J. Dairy Sci. 94:808-823.

LeBlanc, S. J. 2008. Postpartum uterine disease and dairy herd reproductive performance: A review. Vet. J. 176:102-114.

LeBlanc, S. J. 2012. Interactions of metabolism, inflammation, and reproductive tract health in the postpartum period in dairy cattle. Reprod. Domest. Anim. 47(Suppl. 5):18-30.

Lessard, M., N. Gagnon, D. L. Godson, and H. V. Petit. 2004. Influence of parturition and diets enriched in n- 3 or n- 6 polyunsaturated fatty acids on immune response of dairy cows during the transition period. J. Dairy Sci. 87:2197-2210.

Llamas Moya, S., M. Alonso Gómez, L. A. Boyle, J. F. Mee, B. O'Brien, and S. Arkins. 2008. Effects of milking frequency on phagocytosis and oxidative burst activity of phagocytes from primiparous and multiparous dairy cows during early lactation. J. Dairy Sci. 91:587-595.

Mallard, B. A., J. C. Dekkers, M. J. Ireland, K. E. Leslie, S. Sharif, C. Lacey Vankampen, L. Wagter, and B. N. Wilkie. 1998. Alteration in immune responsiveness during the peripartum period and its ramification on dairy cow and calf health. J. Dairy Sci. 81:585-595.

Mann, S., F. A. L. Yepes, T. R. Overton, J. J. Wakshlag, A. L. Lock, C. M. Ryan, and D. V. Nydam. 2015. Dry period plane of energy: Effects on feed intake, energy balance, milk production, and composition in transition dairy cows. J. Dairy Sci. 98:3366-3382.

Mashek, D. G., and D. K. Beede. 2001. Peripartum responses of dairy cows fed energy-dense diets for 3 or 6 weeks prepartum. J. Dairy Sci. 84:115-125.

McCarthy, M. M., S. Mann, D. V. Nydam, T. R. Overton, and J. A. A. McArt. 2015. Short communication: Concentrations of nonesterified fatty acids and $\beta$-hydroxybutyrate in dairy cows are not well correlated during the transition period. J. Dairy Sci. 98:6284-6290.

McNamara, S., J. J. Murphy, M. Rath, and F. P. O'Mara. 2003a. Effects of different transition diets on energy balance, blood metabolites and reproductive performance in dairy cows. Livest. Prod. Sci. 84:195-206.

McNamara, S., F. P. O'Mara, M. Rath, and J. J. Murphy. 2003b. Effects of different transition diets on dry matter intake, milk production, and milk composition in dairy cows. J. Dairy Sci $86: 2397-2408$.

Mee, J. F. 2008. Prevalence and risk factors for dystocia in dairy cattle: A review. Vet. J. 176:93-101.

Moyes, K. M., J. K. Drackley, J. L. Salak-Johnson, D. E. Morin, J. C. Hope, and J. J. Loor. 2009. Dietary-induced negative energy balance has minimal effects on innate immunity during a Streptococcus uberis mastitis challenge in dairy cows during midlactation. J. Dairy Sci. 92:4301-4316.

Murata, H., and T. Miyamoto. 1993. Bovine haptoglobin as a possible immunomodulator in the sera of transported calves. Br. Vet. J. 149:277-283.

Murata, H., N. Shimada, and M. Yoshioka. 2004. Current research on acute phase proteins in veterinary diagnosis: An overview. Vet. J. 168:28-40.

Newsholme, P., R. Curi, S. Gordon, and E. A. Newsholme. 1986. Metabolism of glucose, glutamine, long-chain fatty acids and ketone bodies by murine macrophages. Biochem. J. 239:121-125.

Nonnecke, B. J., K. Kimura, J. P. Goff, and M. E. Kehrli Jr.. 2003. Effects of the mammary gland on functional capacities of blood mononuclear leukocyte populations from periparturient cows. J. Dairy Sci. 86:2359-2368

O'Driscoll, K., G. Olmos, S. Llamas Moya, J. F. Mee, B. Earley, D. Gleeson, B. O'Brien, and L. Boyle. 2012. A reduction in milking frequency and feed allowance improves dairy cow immune status. J. Dairy Sci. 95:1177-1187.

Otter, A. 2013. Diagnostic blood biochemistry and haematology in cattle. In Pract. 35:7-16.

Paape, M. J., D. D. Bannerman, X. Zhao, and J. W. Lee. 2003. The bovine neutrophil: Structure and function in blood and milk. Vet. Res. 34:597-627.

Palmquist, D. L., A. Denise Beaulieu, and D. M. Barbano. 1993. Feed and animal factors influencing milk fat composition. J. Dairy Sci. $76: 1753-1771$.

Park, R. S., R. E. Agnew, F. J. Gordon, and R. W. J. Steen. 1998. The use of near infrared reflectance spectroscopy (NIRS) on undried samples of grass silage to predict chemical composition and digestibility parameters. Anim. Feed Sci. Technol. 72:155-167.

Pithon-Curi, T. C., M. P. De Melo, and R. Curi. 2004. Glucose and glutamine utilization by rat lymphocytes, monocytes and neutrophils in culture: A comparative study. Cell Biochem. Funct. $22: 321-326$.

Porter, M. G., and R. S. Murray. 2001. The volatility of components of grass silage on oven drying and the inter-relationship between drymatter content estimated by different analytical methods. Grass Forage Sci. 56:405-411.

Pullen, D. L., D. L. Palmquist, and R. S. Emery. 1989. Effect on days of lactation and methionine hydroxy analog on incorporation of plasma fatty acids into plasma triglycerides. J. Dairy Sci. 72:49-58.

Rabelo, E., R. L. Rezende, S. J. Bertics, and R. R. Grummer. 2003. Effects of transition diets varying in dietary energy density on lactation performance and ruminal parameters of dairy cows. J. Dairy Sci. 86:916-925

Rabelo, E., R. L. Rezende, S. J. Bertics, and R. R. Grummer. 2005. Effects of pre- and postfresh transition diets varying in dietary energy density on metabolic status of periparturient dairy cows. J. Dairy Sci. 88:4375-4383.

Räber, M., C. J. Lischer, H. Geyer, and P. Ossent. 2004. The bovine digital cushion-A descriptive anatomical study. Vet. J. 167:258 264

Randall, L. V., M. J. Green, M. G. G. Chagunda, C. Mason, S. C. Archer, L. E. Green, and J. N. Huxley. 2015. Low body condition predisposes cattle to lameness: An 8-year study of one dairy herd. J. Dairy Sci. 98:3766-3777.

Roche, J. R., A. W. Bell, T. R. Overton, and J. J. Loor. 2013. Nutritional management of the transition cow in the 21st century- $\mathrm{A}$ paradigm shift in thinking. Anim. Reprod. Sci. 53:1000-1023.

Roche, J. R., N. C. Friggens, J. K. Kay, M. W. Fisher, K. J. Stafford, and D. P. Berry. 2009. Invited review: Body condition score and its association with dairy cow productivity, health, and welfare. J. Dairy Sci. 92:5769-5801. 
Roche, J. R., E. S. Kolver, and J. K. Kay. 2005. Influence of precalving feed allowance on periparturient metabolic and hormonal responses and milk production in grazing dairy cows. J. Dairy Sci. 88:677-689.

Roche, J. R., S. Meier, A. Heiser, M. D. Mitchell, C. G. Walker, M. A. Crookenden, M. V. Riboni, J. J. Loor, and J. K. Kay. 2015. Effects of precalving body condition score and prepartum feeding level on production, reproduction, and health parameters in pasture-based transition dairy cows. J. Dairy Sci. 98:7164-7182.

Rukkwamsuk, T., T. Wensing, and M. J. H. Geelen. 1998. Effect of overfeeding during the dry period on regulation of adipose tissue metabolism in dairy cows during the periparturient period. J. Dairy Sci. 81:2904-2911.

Sauer, M. J., J. A. Foulkes, A. Worsfold, and B. A. Morris. 1986. Use of progesterone 11-glucuronide-alkaline phosphatase conjugate in a sensitive microtitre-plate enzymeimmunoassay of progesterone in milk and its application to pregnancy testing in dairy cattle. J. Reprod. Fertil. 76:375-391.

Scalia, D., N. Lacetera, U. Bernabucci, K. Demeyere, L. Duchateau, and C. Burvenich. 2006. In vitro effects of nonesterified fatty acids on bovine neutrophils oxidative burst and viability. J. Dairy Sci. 89:147-154.

Schroder, K., P. J. Hertzog, T. Ravasi, and D. A. Hume. 2004. Interferon- $\gamma$ : An overview of signals, mechanisms and functions. J. Leukoc. Biol. 75:163-189.

Sheldon, I. M., G. S. Lewis, S. LeBlanc, and R. O. Gilbert. 2006. Defining postpartum uterine disease in cattle. Theriogenology 65:1516-1530.

Sheldon, I. M., E. J. Williams, A. N. A. Miller, D. M. Nash, and S. Herath. 2008. Uterine diseases in cattle after parturition. Vet. J. $176: 115-121$.

Smith, B. I., J. Kauffold, and L. Sherman. 2010. Serum haptoglobin concentrations in dairy cattle with lameness due to claw disorders. Vet. J. 186:162-165.
Stabel, J. R., J. P. Goff, and K. Kimura. 2003. Effects of supplemental energy on metabolic and immune measurements in periparturient dairy cows with Johne's disease. J. Dairy Sci. 86:3527-3535.

Staples, C. R., W. W. Thatcher, and J. H. Clark. 1990. Relationship between ovarian activity and energy status during the early postpartum period of high producing dairy cows. J. Dairy Sci. 73:938-947.

Steen, R. W. J. 1989. A comparison of soya-bean, sunflower and fish meals as protein supplements for yearling cattle offered grass silage-based diets. Anim. Sci. 48:81-89.

Suriyasathaporn, W., C. Heuer, E. N. Noordhuizen-Stassen, and Y. H. Schukken. 2000. Hyperketonemia and the impairment of udder defense: A review. Vet. Res. 31:397-412.

Vandehaar, M. J., G. Yousif, B. K. Sharma, T. H. Herdt, R. S. Emery, M. S. Allen, and J. S. Liesman. 1999. Effect of energy and protein density of prepartum diets on fat and protein metabolism of dairy cattle in the periparturient period. J. Dairy Sci. 82:1282-1295.

Vickers, L. A., D. M. Weary, D. M. Veira, and M. A. G. von Keyserlingk. 2013. Feeding a higher forage diet prepartum decreases incidences of subclinical ketosis in transition dairy cows. J. Anim. Sci. 91:886-894.

Walsh, S. W., E. J. Williams, and A. C. O. Evans. 2011. A review of the causes of poor fertility in high milk producing dairy cows. Anim. Reprod. Sci. 123:127-138.

Williams, E. J., D. P. Fischer, D. U. Pfeiffer, G. C. W. England, D. E. Noakes, H. Dobson, and I. M. Sheldon. 2005. Clinical evaluation of postpartum vaginal mucus reflects uterine bacterial infection and the immune response in cattle. Theriogenology 63:102-117.

Zhang, Q., H. Su, F. Wang, Z. Cao, and S. Li. 2015. Effects of energy density in close-up diets and postpartum supplementation of extruded full-fat soybean on lactation performance and metabolic and hormonal status of dairy cows. J. Dairy Sci.98:7115-7130. 